ISSN: 0213-2060

DOI: http://dx.doi.org/10.14201/shhme201533233261

\title{
LA JUSTICIA DEL REY Y EL DESARROLLO DEL PODER MONÁRQUICO EN EL REINADO DE ALFONSO VIII DE CASTILLA (1158-1214)
}

\author{
Royal Justice and the Expansion of Royal Power under the Reign of Alfonso VIII \\ of Castile (1158-1214)
}

Ignacio ÁLVAREZ BORGE

Depto. de Ciencias Humanas. Facultad de Letras y de la Educación. Universidad de La Rioja. Edificio Vives. C/ Luis de Ulloa, 2. E-26004 Logroño (La Rioja). C. e.: ignacio.alvarez@unirioja.es

Recibido: 2013-10-03

Revisado: 2014-03-17

Aceptado: 2014-10-03

RESUMEN: El reciente aniversario de la batalla de Las Navas de Tolosa ha situado en la mesa del debate historiográfico el reinado de Alfonso VIII de Castilla. Más allá de las consecuencias de la batalla, algunos historiadores están reevaluando el significado histórico del reinado de Alfonso VIII, considerando que tuvieron lugar importantes cambios y desarrollos en la configuración de la monarquía medieval castellana. Una extensión del poder real que se concreta en distintos campos. Uno de ellos es la justicia regia, en cuyo estudio se centra este artículo. Se analiza, en primer lugar, el desarrollo de aparatos burocráticos especializados (merinos mayores y alcaldes de la curia); en segundo lugar, se considera el mayor grado de formalización de los procedimientos judiciales; y, en tercer lugar, se valora el papel que tuvieron los textos escritos en ese desarrollo de justicia del rey.

Palabras clave: Alfonso VIII; Monarquía; Poder regio; Castilla; Merinos mayores; Justicia; Proceso judicial.

Este artículo se ha realizado en el marco del Proyecto de Investigación dirigido por Carlos Estepa y financiado por el MICINN (HAR2009-09599) y de una Ayuda de Investigación de la Universidad de La Rioja (PROFAI 13/05). 
IGNACIO ÁLVAREZ BORGE

LA JUSTICIA DEL REY Y EL DESARROLLO DEL PODER MONÁRQUICO EN EL REINADO DE ALFONSO VIII DE CASTILLA (I I 58 -I 2 I 4)

ABSTRACT: The reign of King Alfonso VIII of Castile (1158-1214) has been placed in the centre of the historiographical debate by the recent anniversary of the Battle of Las Navas de Tolosa. Beyond the consequences of the battle, the whole reign and his historical significance is under revaluation by a sector of the historiography. Several authors consider that in those years took place important changes and developments in Castilian monarchy conformation. They argue about an expansion of royal power in several fields. One of them is royal justice, whose study focuses this paper. The growth of specialised bureaucratic offices (merinos mayores and judges of the royal court) is analysed in the first place. Secondly, the increasing formalization of judicial proceedings. And, finally, the role of writing in the development of royal justice is considered.

Keywords: Alfonso VIII; Monarchy; Royal Power; Castile; Merinos mayores; Justice; Judicial Proceedings.

SUMARIO: 0 Introducción. 1 Notas sobre los documentos conservados. 2 Los aparatos administrativos de la justicia del rey: merinos y alcaldes de la curia. 3 Formalización y burocratización del procedimiento judicial. 4 El papel de lo escrito y lo leído. 5 Conclusiones. 6 Referencias bibliográficas.

\section{INTRODUCCIÓN}

En los últimos años el largo reinado de Alfonso VIII de Castilla (1158-1214) está siendo objeto de una atención notable por los medievalistas. Por supuesto, ese interés debe mucho al reciente aniversario de la batalla de Las Navas de Tolosa (1212) que, al margen de conmemoraciones oficiales, ha suscitado entre los especialistas la revisión de diversos aspectos del reinado ${ }^{1}$. Sea por uno u otro camino, lo cierto es que algunos autores

1 Véase el monográfico «On (de)commemoration: rethinking the battle of Las Navas de Tolosa», publicado por la revista Journal of Iberian Medieval Studies, 2012, vol. 4/1, con 21 contribuciones breves sobre el tema. O los diversos congresos que se han realizado, como el Congreso Internacional Miradas Cruzadas. 1212-2012 Las Navas de Tolosa (Jaén, abril de 2012); la XXIII Semana de Estudios Medievales de Nájera, 1212, un año, un reinado, un tiempo de despegue (Nájera, agosto de 2012); o las VII Jornadas HispanoPortuguesas de Historia Medieval La Península Ibérica en el tiempo de las Navas de Tolosa (Baeza, septiembre de 2012); también la XXXVII Semana de Estudios Medievales de Estella 1212-1214. El trienio que hizo a Europa (Estella, julio de 2010). Otras reuniones científicas y seminarios han sido numerosos, pero destacaré el seminario Alfonso VIII (1158-1214): una época de cambio en el poder real, que se celebró en el CCHS del CSIC en Madrid el 18 y 19 de octubre de 2012, sustentado por el Proyecto de Investigación en cuyo marco se ha realizado este artículo.

En cuanto a la bibliografía sobre el reinado de Alfonso VIII, sigue siendo de referencia imprescindible el estudio de González, Julio. El reino de Castilla en la época de Alfonso VIII. Madrid: Escuela de Estudios Medievales, 1960, 3 vols. A la espera de una revisión completa puede verse también Martínez Díez, Gonzalo. Alfonso VIII rey de Castilla y de Toledo. Burgos: La Olmeda, 1995. Las aportaciones de la historiografía reciente han sido revisadas y comentadas por Estepa Díez, Carlos. «El reino de Castilla de Alfonso VIII (1158-1214)». En Estepa, Carlos; Álvarez, Ignacio y Santamarta, José María. Poder real y sociedad. Estudios sobre el reinado de Alfonso VIII (1158-1214). León: Universidad de León, 2011, pp. 11-63; remito a esa obra para un estado de la cuestión detallado. 
IGNACIO ÁLVAREZ BORGE

LA JUSTICIA DEL REY Y EL DESARROLLO DEL PODER MONÁRQUICO EN EL REINADO

DE ALFONSO VIII DE CASTILLA (I I 58-I 2 I 4)

(entre los que me incluyo) están proponiendo una relectura del reinado de Alfonso VIII para situarlo como un momento especialmente significativo en el proceso histórico de la monarquía medieval castellana ${ }^{2}$. En él se asistió a un importante desarrollo del poder regio, desarrollo que se puede observar en diversos aspectos: la consolidación territorial, el gobierno y la administración o la fiscalidad serían algunos de los más significativos. Algunos autores han acuñado la expresión "centralización monárquica» para referirse a los cambios y transformaciones que, en definitiva, suponen un desarrollo del poder regio o una «extensión del poder real», en la expresión preferida por otros autores ${ }^{3}$. Un proceso que no era sino la otra cara de la moneda del desarrollo que, en paralelo, adquirían los poderes señoriales. Está extendida entre la historiografía la idea de datar el comienzo de esa "centralización monárquica» o "extensión del poder real» unas décadas más tarde, hacia mediados del siglo XIII y, sin duda, la figura de Alfonso X (1252-1284) es un referente muy importante; pero conviene, al menos, llamar la atención sobre los importantes cambios que ya se iniciaron unas décadas antes, en el reinado de Alfonso VIII (1158-1214).

Por supuesto, ese proceso no es exclusivo de la monarquía castellana; se dio en otros reinos peninsulares y en otras zonas de Europa con ritmos, intensidades y características particulares en unas u otras zonas, pero también con algunos significativos paralelismos. Explorar de una manera comparada los paralelismos y las diferencias es una tarea necesaria, pero excede con mucho el objetivo de estas páginas ${ }^{4}$. Como también lo excede el análisis de todos los cambios a que se refiere el proceso de desarrollo del poder regio en el reinado de Alfonso VIII. De todos ellos, quiero llamar la atención sobre el desarrollo de la fiscalidad que ha sido magníficamente estudiado por Carlos Estepa en un trabajo reciente 5 . Por mi parte, dedicaré estas páginas a proponer algunas hipótesis (más que auténticas conclusiones) sobre el desarrollo de la justicia regia 6 .

El argumento que intentaré exponer en este artículo considera que durante el reinado de Alfonso VIII se asiste a un considerable desarrollo institucional de los instrumentos

2 Carlos Estepa, con su equipo en el que me integro, es uno de los autores más destacados en esa revisión del reinado de Alfonso VIII. Véase Estepa, Álvarez y Santamarta, Poder real y sociedad. En las actas de los congresos citados en la nota 1 varias ponencias desarrollan esta propuesta; véase también GARCíA DE Cortázar, José Ángel. «El reinado de Alfonso VIII en el proceso de configuración constitucional del reino de Castilla». En Baró, Juan y SERna, Margarita (eds.). El fuero de Laredo en el octavo centenario de su concesión. Santander: Universidad de Cantabria, 2001, pp. 127-150.

3 Estepa Díez, Carlos. «La monarquía castellana en los siglos XIII-XIV. Algunas consideraciones». Edad Media. Revista de Historia, 2007, vol. 8, pp. 79-98.

4 La bibliografía de referencia sería amplísima y no puede quedar reflejada aquí ni siquiera mínimamente. En 1212-1214. El trienio que hizo a Europa, hay varias contribuciones actualizadas que además aportan numerosas referencias bibliográficas. Una aproximación sintética también en Estepa Díez, Carlos. «Las limitaciones del poder universal: el imperio y las monarquías feudales». En López OjedA, Esther (coord.). 1212, un año, un reinado, un tiempo de despegue. Logrońo: Instituto de Estudios Riojanos, 2013, pp. 15-38.

5 Estepa Díez, Carlos. «La construcción de la fiscalidad real». En Estepa, Álvarez y Santamarta, Poder real y sociedad, pp. 65-94.

6 Estas reflexiones se sustentan sobre otros trabajos anteriores, especialmente Álvarez Borge, Ignacio. Cambios y alianzas. La política regia en la frontera del Ebro en el reinado de Alfonso VIII de Castilla (11581214). Madrid: Consejo Superior de Investigaciones Científicas, 2008; y, sobre todo, Clientelismo regio y acción política. Los merinos mayores de Castilla en el reinado de Alfonso VIII (1158-1214). Madrid: Sociedad Espańola de Estudios Medievales, 2014. 
para el ejercicio de la justicia del rey. No creo necesario insistir en la importancia que las atribuciones judiciales tenían en la configuración de la monarquía. Era algo consustancial a las monarquías medievales occidentales. Por ello, cómo se ejerce la justicia regia o cómo juzga el rey (o por medio de quién) son preguntas muy relevantes en la caracterización del poder regio. Hay una clara evolución a lo largo de la Edad Media, en el trascurso de la cual se va produciendo un desarrollo institucional para el ejercicio de lo que, en principio, era una atribución personal ${ }^{7}$. Mi argumento propondrá que el reinado de Alfonso VIII es un momento significativo en esa evolución por lo que se refiere al desarrollo de unos aparatos burocráticos especializados para el ejercicio de la justicia del rey: los merinos mayores de Castilla y los alcaldes/jueces de la curia regia. También se produce, en correspondencia con ello, una mayor formalización de los procedimientos de la justicia en los que los textos escritos van a ganar importancia.

Antes de entrar en su estudio, son necesarias algunas reflexiones sobre las fuentes.

\section{NotAS SOBRE LOS DOCUMENTOS CONSERVADOS}

Julio González acompañó su monografía sobre el reinado de Alfonso VIII con la edición en dos volúmenes de los documentos regios del período 1145-1217 correspondientes a los reinados de Sancho II, Alfonso VIII y Enrique I. De los 1.035 documentos publicados entonces por ese autor 928 corresponden a Alfonso VIII y a ellos ha ańadido recientemente Carlos Estepa otros 58 documentos más, además de corregir algunas dataciones y proponer otras para algunos documentos no datados o mal fechados por Julio González ${ }^{8}$. De manera que en conjunto contamos con casi 1.000 documentos de Alfonso VIII, que forman el bloque fundamental en el que se basará este estudio. Fundamental, pero no único, porque hay otro buen número de textos que reflejan la actuación judicial del rey y que proceden de colecciones de documentos privados, básicamente de instituciones eclesiásticas. Son textos que no fueron expedidos por la cancillería regia, por lo que no fueron incluidos por los autores mencionados entre los documentos regios, pero sí reflejan de una u otra manera, con mayor o menor detalle, que el rey intervino de manera directa y expresa en la resolución de un conflicto judicial.

El asunto ha sido abordado fundamentalmente desde el punto de vista de la Historia del Derecho y de las Instituciones y la bibliografía de referencia es bastante abundante. A algunas de las obras más significativas me iré refiriendo a lo largo de las páginas siguientes, pero una síntesis general puede verse en SÁnCHEZARCIlla, José. La administración de justicia real en León y Castilla (1252-1504). Madrid: Universidad Complutense, 1980; y, más breve, CaLderón OrTeGa, José Manuel. «La justicia en Castilla y León durante la Edad Media». En La administración de justicia en la Historia de España. Guadalajara: Junta de Comunidades de Castilla-La Mancha, 1999, vol. 1, pp. 21-38. Sin embargo, se está proponiendo una revisión muy importante desde planteamientos metodológicos bien distintos en buena medida articulada en los trabajos de Isabel Alfonso; entre otros, puede verse Alfonso Antón, Isabel. "Judicial rethoric and political legitimation in medieval León-Castile». En Alfonso, Isabel; Kennedy, Hugh y Escalona, Julio (eds.). Building legitimacy. Political discourses and forms of legitimation in medieval societies. Leiden: Brill, 2004, pp. 51-87.

8 Estepa Díez, Carlos. "Apéndice I. Nuevos diplomas de Alfonso VIII. Corrección y atribución de fechas. Nota sobre documentos falsos y sospechosos». En Estepa, Álvarez y Santamarta, Poder real y sociedad, pp. 271-308. 
IGNACIO ÁLVAREZ BORGE

LA JUSTICIA DEL REY Y EL DESARROLLO DEL PODER MONÁRQUICO EN EL REINADO

DE ALFONSO VIII DE CASTILLA (I I 5 8-I 2 I 4)

En conjunto, los documentos privados del período entre 1150 y 1225 pueden aproximarse a unos 6.000 textos?.

La revisión de ambos conjuntos de textos, los regios y los privados, nos ofrece un total de 88 documentos que recogen alguna forma de intervención expresa del rey en la resolución de un pleito. Es una cifra suficiente que permite una visión comprensiva de la administración de justicia del rey. Por supuesto, el rey pudo intervenir en muchas más disputas que las recogidas en esos 88 textos, pero no ha quedado documentado. Además, muchos más documentos regios pudieron realizarse en un contexto de conflictos pero, si no lo dicen expresamente, los he ignorado (excepto en dos o tres casos en que resulta evidente), porque no hacerlo obligaría a un conocimiento detallado de cada contexto específico, un conocimiento que tengo en algunos casos pero del que carezco en muchos otros.

De esos 88 documentos seleccionados, en los que basaré mis propuestas, 54 fueron editados por Julio González, uno añadido por Carlos Estepa y otros 33 proceden de diversas colecciones de distintas instituciones eclesiásticas (destacan en número los de la catedral de Toledo y los de la orden de Santiago). Pero esos 88 documentos forman un bloque muy heterogéneo y bastantes de ellos ofrecen información muy escasa. Por ejemplo, de una pesquisa se nos dice que fue hecha por orden del rey; o que las partes litigantes alcanzan un acuerdo en presencia del rey; o que el rey confirma el acuerdo de los contendientes. Esas u otras informaciones similares indican una intervención del rey, pero no nos ofrecen detalles ni datos precisos sobre el cómo de esa intervención. Denominaremos tipo $B$ a esos documentos que ofrecen información valiosa pero poco detallada. Pues bien, esos documentos tipo $B$ son la mayoría, suman 55 de los 88 documentos seleccionados. Quedan, por lo tanto, otros 33 textos que, siendo también muy variados, sí nos ofrecen información más abundante y nos permitirán proponer, al menos, algunas hipótesis; a estos otros los denominaremos tipo A.

Y una última consideración sobre los documentos en relación con su calidad, con la tradición documental. Del total de 88 documentos seleccionados, 62 proceden de copias cuya calidad también es muy diversa. La mayoría de ellas se contiene en tumbos y cartularios, no faltan algunas insertas en confirmaciones posteriores, también hay algunas copias muy posteriores y de algún texto podemos pensar que es una falsificación. Hay 25 documentos originales y otro cuya tradición no puedo precisar a juzgar por los datos que ofrece su editor ${ }^{10}$. Retomando la clasificación apuntada más arriba, añadiremos que 8

9 Esa cifra es una estimación que no obedece a un recuento detallado, sino aproximado. Pueden verse las tablas que ofrecen los autores del CODIPHIS (García de CorTÁZAR, José Ángel; Munita, José Antonio y Fortún, Luis Javier. Codiphis. Catálogo de colecciones diplomáticas hispano-lusas de época medieval. Santander: Fundación Marcelino Botín, 1999); a esas cifras hay que añadir los textos publicados posteriormente (desde 1997) y los inéditos.

10 GonZÁlez, Alfonso VIII, doc. 766 de 1204, procedente de la orden de Santiago, es calificado como original con algunas dudas [orig.(i)] por su editor.

Por otro lado, el doc. 607 de 1192 es calificado por González como «copia del siglo xiII». Se trata de un documento regio inserto en otro del prior de Calahorra del que existen otras dos ediciones completas (González publicó solo el documento regio); en una de ellas su editor seńala que procede de un pergamino que llevaba un sello de cera, lo que podemos interpretar como un original. Véase SÁrnz RIPA, Eliseo. Colección 
de los 33 documentos tipo $A$ son originales, 24 son copias y el texto dudoso también corresponde a este grupo de los documentos que ofrecen mayor información.

El alto número de copias no invalida, por supuesto, la información contenida en los textos, pero sí supone una llamada de alerta. Dificulta, en primer lugar, una aproximación formal a la tipología documental cancilleresca, porque los textos pudieron ser reelaborados por los copistas. Algunos sin duda lo fueron, fundiendo, por ejemplo, varios documentos en uno para ofrecer una visión más ajustada a los intereses de las instituciones que los conservaron. Además, la intervención regia daba más fuerza a la resolución final del conflicto y bien pudo ser alterada por los copistas para mejorar la posición de sus instituciones en pleitos que a veces se extendieron durante décadas. CURIA

Según he apuntado más arriba, buena parte de mis argumentos en estas páginas intentarán mostrar cómo durante el reinado de Alfonso VIII se produjo un reforzamiento, un desarrollo institucional notable de los instrumentos para el ejercicio de la justicia regia. Un desarrollo de los aparatos administrativos de la monarquía para el ejercicio de la justicia. Aparatos, en plural, porque se trata de dos instancias administrativas en principio independientes. Por un lado, el oficio de merino mayor de Castilla, cuyo ámbito de actuación se extendía a los territorios antiguos del reino, los territorios al norte del Duero; y, por otro lado, un cuerpo especializado de jueces para librar los pleitos que llegaban hasta la curia regia. Veamos cada uno de esos ámbitos.

En primer lugar, los merinos mayores de Castilla. Recientemente he dedicado una monografía a su estudio, tanto de los individuos que ocuparon el oficio en estos ańos como de sus atribuciones, por lo que me referiré ahora a ellos de manera muy breve, remitiendo a ese trabajo para un mayor detalle ${ }^{11}$.

Durante el reinado de Alfonso VIII tiene lugar la formalización del oficio de merino mayor de Castilla, configurándose como uno de los que formaban el núcleo principal de la administración regia junto al mayordomo y el alférez. El merino mayor supone un desarrollo de los anteriores merinos territoriales; no es, por lo tanto, una novedad absoluta, pero sí

diplomática de las colegiatas de Albelda y Logroño (Tomo I: 924-1399). Logroño: Comunidad Autónoma de La Rioja, 1981, doc. 20. Entre las ediciones de González y de Ripa hay otras discrepancias que afectan también a la fecha, pues el segundo fecha el texto en 1195, no en 1192 como hizo González. Ambos elementos, presencia de sello de cera y fecha de 1195, me han sido confirmados por Pablo Díaz Bodegas, director del Archivo Diocesano de Logroño donde se custodia el documento en cuestión (a quien agradezco su amabilidad y disponibilidad para resolver mis dudas) de manera que no me parece que haya problemas en considerar el documento del prior como original. Aun así, claro, el documento regio inserto es una copia. Otra edición del texto en Rodríguez de Lama, Inocencio. Colección diplomática medieval de La Rioja. Logroño: Instituto de Estudios Riojanos, 1979, vol. III, doc. 331.

11 Álvarez Borge, Clientelismo regio. 
IGNACIO ÁLVAREZ BORGE

LA JUSTICIA DEL REY Y EL DESARROLLO DEL PODER MONÁRQUICO EN EL REINADO DE ALFONSO VIII DE CASTILLA (I I 5 8-I 2 I 4)

implica un avance muy significativo ${ }^{12}$. He argumentado en otro lugar que su formación y desarrollo constituye un instrumento para la aplicación del poder regio, de los contenidos que va adquiriendo el poder regio, contenidos que se refieren sobre todo a la fiscalidad y la justicia ${ }^{13}$. Y ahora nos interesa especialmente la justicia, siendo los merinos mayores un potente instrumento para el ejercicio de la superioridad jurisdiccional del rey en las zonas al norte del Duero. Zonas donde, por un lado, los poderes señoriales se han desarrollado con mucha intensidad, y con ellos las atribuciones jurisdiccionales de los señores. Y zonas donde, por otro lado, hasta ahora el peso mayor de la administración regia -aunque existían los merinos territoriales, como hemos apuntado- recaía en los tenentes, miembros de la nobleza -muchos de ellos de la alta nobleza- que, aunque ejercen en teoría un poder delegado del rey, en la práctica mezclan sus intereses patrimoniales privados con el ejercicio de un oficio público. Sobre esa tupida maraña de intereses señoriales se extiende también la superioridad jurisdiccional del rey (que contribuye a dar contenido a lo que en otros lugares he denominado señorío jurisdiccional regio, siguiendo una terminología propuesta hace años por Carlos Estepa). Superioridad que suponía que la justicia del rey se extendía a los pleitos entre señores, o entre vasallos de diferentes señores, o en ocasiones también a pleitos entre señores y sus vasallos, además, claro, de los conflictos que afectaban a los lugares sujetos directamente a la jurisdicción regia, los realengos y las behetrías, y también de los casos reservados a la justicia regia, los que más adelante se denominarán casos de corte.

En origen correspondía a los tenentes ejercer la justicia en los lugares que gobernaban por delegación regia, pero en el reinado de Alfonso VIII la administración de la justicia del rey corresponderá cada vez más a los merinos mayores y a sus oficiales delegados en los distritos, los merinos menores. No hay todavía una total sustitución de las atribuciones jurisdiccionales de los tenentes, y la articulación de las funciones de unos y otros, tenentes y merinos, nos resulta peor conocida de lo que desearíamos; aunque no creo que haya que buscar una definición formal de funciones -que no existía en esta época-, sino que la actuación judicial de cada tenente podía depender mucho de su propia personalidad social y política ${ }^{14}$. Pero, en cualquier caso, sí hay una progresiva sustitución de los tenentes por los merinos en estos aspectos. Sustitución progresiva, como digo, pero que avanzó de manera sustancial en el reinado de Alfonso VIII, precisamente por el desarrollo institucional de los merinos mayores ${ }^{15}$.

12 Sobre los orígenes y los precedentes de los merinos mayores Montenegro Valentín, Julia. «Algunas consideraciones sobre los orígenes del merino mayor». Anuario de Historia del Derecho Español, 1997, vol. 67, pp. 1091-1106; Estepa DíEz, Carlos. «Sobre los orígenes de los merinos mayores en León y Castilla». En Mínguez, José María y Ser, Gregorio del (eds.). La Península en la Edad Media. Treinta años después. Estudios dedicados a José Luis Martín. Salamanca: Ediciones Universidad de Salamanca, 2006, pp. 87-100; y ÁlvarEZ Borge, Clientelismo regio, pp. 13-16.

13 Álvarez Borge, Ignacio. Monarquia feudal y organización territorial. Alfoces y merindades en Castilla (siglos X-XIV). Madrid: Consejo Superior de Investigaciones Científicas, 1993.

14 Algunos ejemplos en Álvarez Borge, Cambios y alianzas, pp. 377-386.

15 Sobre la evolución de las tenencias en Castilla en el siglo XIII un estudio muy completo en EsTEPA Díez, Carlos. «Los territorios: II. Tenencias y tenentes». En La formación de la Corona de Castilla, en preparación (agradezco al autor haberme permitido consultar su trabajo inédito); y una introducción al tema para el reino de León (más limitada también cronológicamente) en Bianchini, Janna. "The distribution of tenancies in León, c. 1200-1250: charter evidence for a history of power». Journal of Medieval Iberian Studies, 2013, vol. 5/1, pp. 33-46. 
Una parte muy importante de lo que los documentos conservados reflejan sobre el ejercicio del oficio de los merinos mayores tiene que ver con su participación en la resolución de pleitos y conflictos, con la administración de justicia. Documentamos, sobre todo, a los merinos mayores actuando como pesquisidores y como jueces ${ }^{16}$. Como cuando hacia 1183 el rey ordenó a su merino mayor (denominado uillico en el documento) Lope Díaz de Fitero que realizara una pesquisa para averiguar el fuero del lugar de Arroyal (precepit domino Lupo, uillico suo, qui preerat omnibus aliis uillicis, quod perquireret in circumiacentibus uillis que sunt in facie de Arroial qualem forum in tempore imperatoris et regis Sancii haberet hec predicta uilla ${ }^{17}$. O como cuando por esas mismas fechas, en 1182, el merino mayor juzgó y dictó sentencia (iudicauit) en uno de los episodios del conflicto que enfrentó a los monasterios de San Juan de Burgos y de San Cristóbal de Ibeas de Juarros con el concejo y con los señores de Santa Cruz de Juarros: Et rex mandauit Lop Diaz de Fitero quod iudicaret illud iudicium... et secundum cartularium iudicauit Lop Diaz ${ }^{18}$.

Son dos ejemplos entre otros muchos y, si bien se podría argumentar que el primer caso (la realización de pesquisas) corresponde a una actuación más gubernativa que judicial, el límite entre uno y otro tipo de atribuciones era muy difuso y distaba mucho de estar establecido formalmente.

El desarrollo institucional de los merinos mayores se acompaña de un aparato burocrático más amplio, con una red de oficiales dependientes y delegados, porteros y sobre todo merinos menores, que comenzamos a ver desplegarse ahora al servicio de los merinos mayores. Por lo que se refiere a los merinos menores, esa red se irá definiendo y formalizando con el tiempo. No siempre es fácil determinar la posición de los distintos merinos que se documentan en los distritos y en los ámbitos locales (merinos menores dependientes de los merinos mayores, pero también merinos de los tenentes, de los concejos y merinos señoriales), pero en el reinado de Alfonso VIII ya se documenta claramente un buen número de merinos en los distritos dependientes de los merinos mayores; en definitiva, una infraestructura administrativa al servicio de los merinos mayores ${ }^{19}$.

Precisamente, en el ejemplo citado más arriba, cuando el rey ordenó a su merino mayor hacia 1183 que realizara una pesquisa para averiguar el fuero de Arroyal, el merino mayor, Lope Díaz de Fitero, ordenó a su vez a un merino menor, Pedro Mella, que fuera él quien, en compañía de un clérigo capellán del señor del lugar, llevara a cabo la pesquisa (Et precepit dominus Lupus uillicus suo, Petro Mella, ex parte regis quo ipse perquireret) ${ }^{20}$.

El segundo aparato o instancia administrativa que se desarrolla ahora para el ejercicio de la justicia regia es un cuerpo específico y especializado de alcaldes que libran los pleitos que llegan hasta la curia regia. Sobre este aspecto mis conclusiones son algo menos firmes, porque hay bastantes documentos que recogen actuaciones de los merinos mayores y menores, pero solo unos pocos que se refieren a estos alcaldes de la curia. Pero,

16 No desarrollaré ahora estos aspectos que he estudiado con detalle en Álvarez Borge, Clientelismo regio, pp. 98-118.

17 Véase González, Alfonso VIII, doc. 406.

18 Peña Pérez, Francisco Javier. Documentación del monasterio de San Juan de Burgos (1091-1400). Burgos: Ediciones J. M. Garrido Garrido, 1983, doc. 43.

19 Remito de nuevo a Álvarez Borge, Clientelismo regio, pp. 124-125.

20 GonZÁlez, Alfonso VIII, doc. 406. 
aunque con alguna prudencia, creo que hay evidencias suficientes para sostener que, como sucede también en el reino de León, el rey ahora comienza a dotarse de un cuerpo especializado de jueces que actúan en su curia y libran los pleitos en su nombre.

Desde tiempos anteriores la curia regia venía actuando como tribunal de justicia. Los pleitos que llegaban hasta el rey eran resueltos por él, pero actuando con el consejo de la curia y en el contexto de la curia. El asunto fue estudiado en profundidad y desde el punto de vista de la Historia de las Instituciones por Claudio Sánchez-Albornoz y Nilda Guglielmi ${ }^{21}$. Los documentos que recogen actuaciones judiciales de la curia y/o del rey en la curia son muy variados desde el punto de vista formal y ofrecen información muy diversa. No es raro que el rey designe dentro de la curia o en la curia a un juez o un grupo de jueces para que libren un pleito determinado. Serían lo que podríamos denominar jueces designados dentro de la curia, que actúan en un momento determinado y en relación con un pleito concreto. A veces son magnates o eclesiásticos destacados miembros de la curia en quienes el rey delega su actuación judicial. Otras veces, y aunque la composición de la curia era variable y con frecuencia nos resulta mal conocida, no parecen tanto miembros, diríamos, ordinarios o regulares de la curia, sino más bien expertos en leyes a quienes el rey pide que resuelvan en su curia un determinado caso. Pero Nilda Guglielmi documentó cómo en el reino de León en las últimas décadas del siglo XII y en las primeras del XIII esos que podemos denominar jueces designados son sustituidos por otros que podemos denominar jueces ordinarios. Un grupo de jueces permanentes, iudices curiae, probablemente elegidos por el rey para librar los pleitos que llegaban ante él durante un período determinado y ya no para un caso concreto $^{22}$. Esos jueces permanentes serán los antecesores de los posteriores alcaldes de corte, cuyas funciones quedarán recogidas en los textos legislativos y en cuadernos de cortes de la segunda mitad del siglo Xiır. En palabras de la autora citada: «Tal vez la complejidad creciente que la administración pública en general conoció conforme pasaban los años, su diversificación y especialización correspondiente a un lento pero efectivo progreso político fueron las causas determinantes de la estabilización de los iudices curiae que pronto han de dejar paso a los alcaldes de corte y sobrejueces, en el camino de la burocratización estatal» ${ }^{23}$.

Creo que en el reino de Castilla se dio un proceso similar a lo largo del reinado de Alfonso VIII. En los ańos 70 y comienzos de los 80 se documentan varios casos de pleitos que llegaron a la curia regia, para cuya resolución el rey designó a uno o varios de sus miembros para que actuaran como jueces y libraran dichos pleitos. Así, en 1175 o 1185 el monasterio de Cardeña y los hombres de Peñafiel y Fuentidueña llevaron a la curia del rey su disputa sobre la iglesia de Santa María de Cuevas, y el rey ordenó que librara el pleito el conde Gómez (Manzanedo), quien así lo hizo dictando finalmente sentencia

21 Véase SÁnchez-Albornoz, Claudio. La curia regia portuguesa. Siglos XII y XIII. Madrid: Centro de Estudios Históricos, 1920; y Guglielmi, Nilda. "La curia regia en León y Castilla (I)». Cuadernos de Historia de España, 1955, vol. 23-24, pp. 116-267.

22 Guglielmi, «La curia regia», pp. 165-167, donde cita varios ejemplos del reino de León, el primero de ellos ya en 1178 .

23 Guglielmi, «La curia regia», p. 167. 
favorable al monasterio ${ }^{24}$. Algo parecido sucedió poco después, quizás hacia 1177 , en un pleito entre la orden de Santiago y el arzobispo de Toledo sobre las heredades que la orden tenía en Tajuña y en Villamanrique de Tajo. Tras varios episodios, las partes acordaron llevar el pleito a la curia regia, donde el rey designó en esta ocasión a otros tres magnates para que libraran el pleito: el conde Nuńo (de Lara), el conde Gonzalo de Marańón y el mayordomo regio Rodrigo Gutiérrez (Girón) ${ }^{25}$. Otros casos son también similares, aunque podrían ofrecer algunos matices. Los monasterios de San Juan de Burgos y San Cristóbal de Ibeas protagonizaron un largo pleito con el concejo de Santa Cruz de Juarros y sus seńores sobre derechos de pastos. En uno de los episodios de ese pleito, sobre el que volveremos más adelante, llevaron su disputa ante el rey, cuando este se encontraba en Burgos. El rey, por su parte, ordenó entonces que librara el pleito Lope Díaz de Fitero, que era el merino mayor. En el texto que se conserva no se dice que lo hiciera precisamente por su condición de merino, pero parece lógico que así fuera ${ }^{26}$. En otros casos no conocemos el nombre del juez designado ni podemos asegurar que fuera un miembro de la curia. Como hacia 1177, cuando pleiteaban el monasterio de Fitero y el concejo de Alfaro y su señor sobre aprovechamiento de aguas. Llevaron también su pleito ante el rey, cuando este se encontraba en la zona (en Préjano, cerca de Arnedo en la actual Rioja); ante la negativa de una de las partes a llegar a un acuerdo, el rey ordenó que el pleito fuera librado por la curia, donde se decidió que el rey designara a un hombre para averiguar la verdad. No sabemos su nombre ni su resolución y, aunque hay claros paralelismos con otros casos de jueces designados en la curia regia, su función podría corresponder también a la de un pesquisidor. El texto que se conserva es una traducción realizada a comienzos del siglo XVIII, lo que nos priva de muchos detalles, pero sí nos ofrece alguno muy valioso al mencionar los miembros de la curia que acompañaban en ese momento al rey: el conde ¿¿Sancho Pérez? (seguramente un error por Nuño Pérez), el conde Gómez, Pedro Rodríguez de Nájera (también de los Lara), el mayordomo Rodrigo Gutiérrez, su hermano ¿Pedro Rodríguez? (probablemente otro error por Pedro Gutiérrez) y el anfitrión del rey y su corte, Gonzalo Copelín, un personaje destacado en la zona de la frontera del Ebro en esos años y del que, sin embargo, sabemos poco ${ }^{27}$. A varios del ellos los hemos visto en otros documentos de esos mismos años y también como jueces designados por el rey para resolver pleitos en la curia regia.

24 Martín Postigo, María de la Soterraña. Santa María de Cárdaba. Priorato de Arlanza y granja de Sacramenia. Valladolid: Secretariado de Publicaciones de la Universidad de Valladolid, 1979, doc. XIII. Lamentablemente no se conserva el documento original, que solo se conoce a través del texto que publicara en su día Berganza (Berganza, Francisco de. Antigüedades de España. En Madrid: por Francisco del Hierro, 1721, vol. II, doc. 32, p. 386); según ese autor el documento estaba datado en la era MCCXIII correspondiente al año 1175, pero añade que Delataque fuit altercatio coram Domino Rege Allefonso ad Curiam, que facta fuit in Naxera; por lo tanto el pleito se libró en la curia de Nájera que tuvo lugar muy probablemente a comienzos de 1185. Cabe pensar, entonces, que se leyera o copiara mal la fecha, debiendo faltar una decena; sería la era MCCXXIII correspondiente al año 1185.

25 Martín Rodríguez, José Luis. Origenes de la orden militar de Santiago (1170-1195). Barcelona: Consejo Superior de Investigaciones Científicas, 1974, doc. 115. El texto que se conserva no lleva fecha y fue datado por su editor hacia 1180, pero hay que tener en cuenta que el conde Nuño murió en 1177.

26 Peña Pérez, San Juan, doc. 43 de 1182.

27 García Turza, Francisco Javier. Documentación medieval del monasterio de San Prudencio de Monte Laturce (siglos X-XV). Logrońo: Instituto de Estudios Riojanos, 1992, doc. 44. 
IGNACIO ÁLVAREZ BORGE

LA JUSTICIA DEL REY Y EL DESARROLLO DEL PODER MONÁRQUICO EN EL REINADO

DE ALFONSO VIII DE CASTILLA (I I 5 8-I 2 I 4)

Otros documentos nos informan de que el rey libró pleitos en su curia o con jueces de su curia, pero de una manera genérica, sin especificar quiénes eran. A algunos de ellos me referiré más adelante, pero ahora me interesa destacar que, frente a los textos mencionados que muestran la actuación de jueces designados en los ańos 70 y comienzos de los 80 , otros textos unos años posteriores muestran ya la existencia en la curia regia de jueces ordinarios o jueces permanentes ${ }^{28}$. Comenzamos a ver algunos ejemplos en los años 90 y con más claridad y definición ya a comienzos del siglo XIII. Veremos también cómo en los primeros momentos esos jueces del rey se documentan al norte del Duero (años 90) en las zonas de actuación del merino mayor, pero no tardarán en quedar bien delimitadas las atribuciones judiciales de los merinos mayores al norte del Duero y las de los jueces de la curia al sur. Al menos esa es mi hipótesis a partir de unos textos escasos pero, a mi juicio, suficientemente reveladores. Los documentos van a referirse a esos jueces regios como alcaldes, que era la expresión equivalente en romance ${ }^{29}$.

Sabemos que en 1195 García Ruiz era alcalde del rey y actuaba en el ámbito de todo el reino. El prior de Calahorra se refiere a él diciendo qui est per totum suum regnum alcalde ex mandato regis. Había librado un pleito entre el monasterio de Albelda y el concejo de Ausejo (en la actual Rioja) sobre el nombramiento del cura de la iglesia de San Valerio de Ausejo. El texto que se conserva contiene inserta la confirmación hecha por el rey de la sentencia que había dado García Ruiz en la curia regia: Sciatis quod Garsias Roiz indicanit ita et dedit istud iudicium in curia mea de illa baraia et de illa contenta (sic) quam uos concilium de Agoseio habeatis cum priore Sancti Martini de Albelda ${ }^{30}$. Este alcalde García Ruiz ha de corresponder con García Ruiz de Toledo, también documentado como alcalde regio muy poco después, como veremos a continuación.

En 1196, documentamos otros alcaldes/jueces del rey. Se trata ahora de un grupo de cuatro: Gonzalo Pérez de Torquemada, Gutierre Díaz de Sandoval, Ordońo de Torme y García Ruiz de Toledo, quienes juzgaron por orden del rey otro de los episodios del pleito entre los monasterios de San Juan de Burgos e Ibeas de Juarros con el concejo de Santa Cruz de Juarros. Hemos visto más arriba cómo libró un juicio sobre ello el merino Lope Díaz de Fitero por orden del rey en 1182. Pero la sentencia no solucionó la disputa y en 1196 las partes acudieron con sus procuradores o voceros ante el rey cuando este se encontraba en Peñafiel y el rey ordenó que libraran el pleito sus alcaldes mencionados ${ }^{31}$. Uno de los alcaldes de 1196, Gutierre Díaz de Sandoval, también fue merino mayor de

28 Conviene en este punto tener en cuenta todavía otro documento, ya de 1209, en que el rey designa a unos jueces para resolver un pleito. Se trata de una disputa entre el cabildo de Burgos y el capellán de la reina sobre unos molinos en Burgos. El rey ordenó que el pleito fuera librado por el arcipreste de Frías y por un hermano del deán, ambos muy próximos al cabildo; creo que ese hecho y el que la otra parte implicada fuera el capellán de la reina -no sé si por sí mismo o en nombre de la reina- explican la actuación del rey. Garrido Garrido, José Manuel. Documentación de la catedral de Burgos (1184-1222). Burgos: Ediciones J. M. Garrido Garrido, 1983, doc. 418.

29 Es muy expresiva la frase del fuero de Los Balbases (Burgos), en 1135, que se refiere a los judices..., qui vulgo alcaldes vocantur; MARTínez Díez, Gonzalo. Fueros locales en el territorio de la provincia de Burgos. Burgos: Caja de Ahorros Municipal de Burgos, 1982, doc. XC, $\$ 3$.

30 González, Alfonso VIII, doc. 607; Sáinz Ripa, Albelda y Logroño, doc. 20; Rodríguez de Lama, Colección diplomática, vol. III, doc. 331.

31 Peña Pérez, San Juan, doc. 58. 
Castilla unos años después, entre 1198 y 1205, y podríamos hablar de una trayectoria, de una carrera política o cursus honorum al servicio del rey. Y, aunque no se documenta de una manera tan clara como en el caso anterior, también creo que estos alcaldes eran jueces permanentes, no fueron designados específicamente para librar este pleito. La presencia en ambos casos de García Ruiz avalaría esta interpretación.

Este texto de 1196 es el último en el que vemos actuar a alcaldes del rey o de la curia regia en las zonas al norte del Duero. No tardaremos en documentar de nuevo curie regis alcaldes, pero ya al sur del Duero. Parece que poco a poco fue perfilándose de manera definitiva que la justicia del rey al norte del Duero sería impartida por los merinos mayores, mientras que en la curia se va desarrollando un cuerpo de alcaldes/jueces permanentes que actuarán en los pleitos referidos a las zonas al sur del Duero.

Varios documentos entre 1207 y 1210 documentan a Pedro Vidas y Minaya como curie regis alcaldes. El más significativo es quizás el último de 1210. En esa fecha el rey confirmó un acuerdo (auenentiam) entre la orden de Santiago y el concejo de Ocaña sobre los fueros de ese lugar. El acuerdo fue alcanzado en presencia de varios testigos, entre ellos Mienaya et P. Vidas, curie regis alcaldes. El texto que se conserva especifica que el acuerdo se estableció en presencia del rey estando este en Moratalaz. Probablemente el rey actuó como intermediario, favoreciendo o incluso forzando el acuerdo, bien directamente o, más probablemente, a través de los alcaldes citados ${ }^{32}$.

Quizás la presencia de los alcaldes de la curia regia como testigos nos esté indicando una actuación mayor de la curia en la resolución de este conflicto. En cualquier caso, este texto nos informa con claridad de la existencia de los dos alcaldes de la curia y de sus nombres. Y esa información, a su vez, nos permite interpretar y situar en su contexto otra, contenida en otros documentos menos explícitos de esos mismos años. Así, dos documentos de 1208 contienen sendas confirmaciones regias de los términos entre los concejos de Segovia y Madrid, en un caso, y entre el concejo de Segovia y la orden de Santiago, en otro. En ambos casos el rey confirma los términos que fueron establecidos por su alcalde Minaya (omnes illos terminos quos Minnaya, dilectus alcaldus meus, determinauit de mandato meo) ${ }^{33}$. Y Minaya también había participado el año anterior, 1207, en la delimitación de términos entre Sepúlveda y Fresno. De nuevo el documento conservado contiene la confirmación por el rey del acuerdo entre las partes (conuenienciam), pero en el texto se indica también que Minaya erat cum illis quando fecerunt istam conuenienciam et posuerunt istos moiones ${ }^{34}$. Como en el primer ejemplo de 1210, no parece difícil pensar que esta referencia a Minaya aluda en realidad a una intervención mayor o más intensa que la expresada formalmente. Minaya estaba con ellos cuando alcanzaron el acuerdo y probablemente fue el artífice del mismo. No se dice ahora cuál era la posición o cargo de Minaya, pero su actuación como alcalde de la curia regia me parece clara a la luz de los otros documentos citados. A su vez, estas referencias nos permiten identificar con bastante probabilidad al alcalde regio

32 González, Alfonso VIII, doc. 868; y Rivera Garretas, Milagros. La encomienda, el priorato y la villa de Uclés en la Edad Media (1174-1310). Madrid: Consejo Superior de Investigaciones Científicas, 1985 , doc. 59.

33 González, Alfonso VIII, docs. 822 y 828.

34 González, Alfonso VIII, doc. 809. 
IGNACIO ÁLVAREZ BORGE

LA JUSTICIA DEL REY Y EL DESARROLLO DEL PODER MONÁRQUICO EN EL REINADO

DE ALFONSO VIII DE CASTILLA (I I 5 8-I 2 I 4)

Minaya con el individuo llamado Minaya de San Esteban (probablemente San Esteban de Gormaz), quien también fue testigo en 1202 cuando el rey estableció un acuerdo entre el concejo de Ocaña y la orden de Santiago sobre heredades en Ontígola (Toledo) ${ }^{35}$.

Nada más sabemos sobre Minaya, aparte de su probable procedencia de San Esteban de Gormaz. Ni siquiera podemos estar seguros de su nombre, porque Minaya era un apelativo, no un nombre propiamente dicho; al menos no lo era originariamente, aunque pudo haber derivado ya en un nombre ordinario en esos años ${ }^{36}$.

El segundo alcalde de la curia regia documentado en 1210 es Pedro Vidas. Esa es la única ocasión en que se documenta como tal, pero otros textos muestran su actividad al servicio del rey o su participación en la resolución de pleitos y disputas. Es muy significativa la donación que recibió del rey en junio de 1211 junto a Pedro Fernández, apenas unos meses antes de que Pedro Fernández se convirtiera en merino mayor de Castilla. A ambos les entregó el rey Avengamar por mitades y al futuro merino le confirmó también sus heredades en Moya (ambos lugares en Cuenca). La donación a Pedro Fernández la motiva el rey por su participación en la repoblación de Moya, la de Pedro Vidas por los servicios prestados en los negocios del rey (in negociis meis). No es difícil ver en esos negocios su papel como alcalde de la curia regia ${ }^{37}$.

Otros alcaldes/jueces se documentan en pleitos en los que interviene el rey de una u otra manera y actuando al servicio del rey, pero no son alcaldes de la curia regia, sino de importantes concejos como Toledo o Burgos ${ }^{38}$.

\section{FORMALIZACIÓN Y BUROCRATIZACIÓN DEL PROCEDIMIENTO JUDICIAL}

Los alcaldes de la curia regia y los merinos mayores (y el cuerpo de merinos menores y otros oficiales de ellos dependientes) son los aparatos administrativos que hacen posible y efectivo el desarrollo de la justicia regia en el reinado de Alfonso VIII. En paralelo y en clara relación con ello se produce también una mayor formalización y burocratización del proceso judicial.

¿Cómo juzga el rey? o ¡cómo se juzga en nombre del rey? son las preguntas a las que intentaremos dar algunas respuestas en este apartado ${ }^{39}$.

35 González, Alfonso VIII, doc. 729. Nótese que en el texto figura la referencia a otros alcaldes, pero se trata de alcaldes de Toledo, no de la curia regia.

36 Sería un compuesto del posesivo romance «mi» o «mío» y el sustantivo vasco «anai/anaia», con el significado de «hermano» o «mi hermano» en sentido figurado. Así se ha interpretado en el caso más conocido de Álvar Fánez Minaya, amigo y lugarteniente del Cid.

37 González, Alfonso VIII, doc. 878. Me he referido con más detalle a Pedro Vidas, a su relación con el merino Pedro Fernández (ambos estuvieron vinculados a la orden de Santiago) y a otros documentos posteriores ya en el reinado de Fernando III, en Álvarez Borge, Clientelismo regio, pp. 80-81 y 169.

38 Alcaldes de Toledo en González, Alfonso VIII, doc. 766 de 1204 y doc. 882 de 1211; y HerNÁNDEZ, Francisco Javier. Los cartularios de Toledo. Catálogo documental. Madrid: Fundación Ramón Areces, 1985, doc. 360 de 1215. Y alcaldes de Burgos en Peña Pérez, San Juan, doc. 60 de c 1200.

39 Entre los estudios sobre el proceso judicial desde una perspectiva institucionalista véase Prieto Morera, Agustín. «El proceso en el reino de León a la luz de los diplomas». En El reino de León en la Alta Edad Media, vol. II. Ordenamiento jurídico del reino. León: Centro de Estudios e Investigación San Isidoro, 1992, pp. 381-518. 
No creo que en este período esté establecido y perfectamente formalizado el proceso judicial, que haya normas cerradas que deban seguirse en todos los casos. Los textos legislativos de la segunda mitad del siglo xiII y posteriores irán definiendo un proceso judicial de ese tipo. Ahora creo que el proceso judicial es más abierto en función de las circunstancias de cada caso y cada momento. Pero, aunque el procedimiento a seguir en los juicios no esté cerrado y definido, sí creo que se va avanzando hacia una mayor formalización y burocratización. Se ha advertido más arriba que la cantidad de información que proporcionan los documentos es muy diversa, en buena medida por su propia calidad, abundando las copias, reelaboraciones y refundiciones, pero contando con eso, sí hay un número significativo de textos que muestran cómo se va avanzando en el proceso indicado. Esos textos muestran que en bastantes casos el procedimiento seguido por el rey, los merinos o los alcaldes de la curia responde a pautas cada vez más consistentes.

Cuando los pleitos son resueltos por los merinos, los documentos muestran que las partes contendientes pueden acudir directamente a ellos o acudir al rey y este ordenar actuar al merino. Ya hemos mencionado uno de los episodios del pleito entre los monasterios de Ibeas y San Juan de Burgos con el concejo de Santa Cruz de Juarros en el que las partes acudieron al rey en Burgos en 1182 y este ordenó que librara el pleito Lope Díaz de Fitero, quien en esos años era merino mayor. También en el pleito de Arroyal ya mencionado los vecinos acudieron al rey en 1183 y este ordenó igualmente que actuara el merino mayor ${ }^{40}$. Pero otras veces las partes acuden directamente al merino mayor, como cuando el monasterio de Aguilar y los herederos del monasterio de San Cristóbal de Villímar acudieron en 1208 al merino mayor García Rodríguez Barba para que juzgara el pleito que les enfrentaba sobre un monasterio en Los Balbases ${ }^{41}$.

Otros pleitos, como hemos ido viendo, se libran por el rey en su curia. Todavía tampoco está determinado qué casos se libran en la curia, sea en calidad de tribunal de apelación, sea por el tipo de casos cuestión (los que después se conocerán como casos de corte). Será algo que también se irá estableciendo posteriormente. Ahora vemos cómo al rey y a su curia llegan conflictos de diverso tipo en función de la capacidad de los litigantes de acceder al rey, sea por su posición social o económica, sea por las posibilidades de acceder físicamente a una corte itinerante ${ }^{42}$.

Cuando dos partes contendientes solicitaban justicia al rey podían hacerlo directamente o bien mediante representantes o voceros. En 1210 veinte vecinos de Olmedo calificados como boni homines acudieron ante el rey en Mońibas, una aldea de Segovia situada a unos $40 \mathrm{~km}$, para defender su causa contra el monasterio de Silos sobre la iglesia de San Cristóbal de Olmedo y una heredad en el vecino lugar de Puras: quod uiginti boni homines de Ulmeto uenerunt ante me, Aldefonsum, Dei gratia regem Castelle

40 Peña Pérez, San Juan, doc. 43, para el pleito de Juarros; y González, Alfonso VIII, doc. 406, para el pleito de Arroyal.

${ }^{41}$ Fallaronse en abinencia el prior et don Gutier Munioz et suos herederos que fossen a iudizio a Fromesta a Garci Roiz, merino del rei; Rodríguez de Diego, José Luis. Colección diplomática de Santa María de Aguilar de Campoo (852-1230). Valladolid: Junta de Castilla y León, Consejería de Cultura y Turismo, 2004, doc. 210.

42 Guglielmi, «La curia regia», pp. 190-193. 
et Toleti, in Munione Viuas, adea de Secobia ${ }^{43}$. Algo parecido debió suceder en 1194 cuando los hombres de Ledigos (Palencia) acudieron al rey en Carrión para solicitar justicia en su disputa con Saldaña y su tenente sobre términos; o en 1183 cuando los vecinos de Arroyal (Burgos) acudieron ante el rey en Palencia también para solicitar justicia, en este caso contra su señor ${ }^{44}$. Pero otras veces los litigantes actúan por medio de procuradores o voceros. Estos podían ser quienes acudieran ante el rey y su curia a solicitar justicia en nombre de sus representados, como en el episodio del pleito entre los monasterio de Ibeas y San Juan con el concejo de Santa Cruz de Juarros en 1196. En nombre de los primeros acudió ante el rey en Peñafiel Fernando Fernández de Castro y en nombre de los segundos Álvar Garça (¿García?) ${ }^{45}$. Otras veces los procuradores parecen actuar una vez que el pleito ya ha llegado al rey y a la curia y el proceso judicial ya se ha iniciado. Así en el pleito entre la orden de Santiago y al arzobispo de Toledo hacia 1177 sobre las heredades de la orden en Tajuña y Villamanrique de Tajo, los voceros, Lope Díaz de Mena por el maestre y Lope Díaz de Fitero por el arzobispo, se mencionan una vez que las partes ya han acudido a juicio al rey y este hubo designado a los jueces que habrían de librar el pleito en su curia ${ }^{46}$. Unos años más tarde, hacia 1184-1186, la orden pleiteó también con el conde Fernando (de Lara) sobre una heredad en Villalón y llevaron el pleito ante el rey y en el trascurso del pleito actuaron los voceros de ambas partes: de nuevo el merino Lope Díaz de Fitero por el conde y el maestre Fernando Díaz por la orden ${ }^{47}$. Y cuando los contendientes acuden al merino mayor en busca de justicia también pueden hacerlo mediante sus procuradores, como hicieron los mencionados monasterio de Aguilar y herederos del monasterio de San Cristóbal de Villímar en 1208 cuando fueron a juicio ante el merino mayor García Rodríguez Barba en Frómista. El procurador del monasterio fue un monje, fray Sebastián, y el del los herederos Diego Muñoz de Pedrosa ${ }^{48}$.

Acudir a juicio ante el rey y su curia no siempre era la primera opción, aunque a veces sí era la manera más eficaz de intentar resolver un conflicto. Intentarlo al menos, porque la sentencia regia tampoco era garantía de que la disputa se resolviera definitivamente. Ya hemos mencionado algún caso de disputas que se prolongan en el tiempo y aún veremos otros más; pero mientras tanto el juicio del rey sí podía aparecer como la mejor opción. Las idas y venidas de una instancia judicial a otra se describen en el texto que recoge el pleito entre la orden de Santiago y el arzobispo de Toledo sobre las heredades de Tajuña y Villamanrique de Tajo. En un primer momento y en fecha desconocida el maestre y el arzobispo acudieron a juicio en Toledo, pero ese juicio o no llegó a celebrarse o su resultado no satisfizo a las partes (o quizás solo a la orden) y el maestre apeló a Roma. Pasado algún tiempo, en la conquista de Cuenca el arzobispo pidió al rey que convenciera al maestre para que este renunciara a la apelación ante el

43 González, Alfonso VIII, doc. 863. doc. 406.

El pleito entre Ledigos y Saldaña en GonzÁlez, Alfonso VIII, doc. 632; el de Arroyal en Ibid.,

45 Peña Pérez, San Juan, doc. 58.

46 Martín Rodríguez, Orden de Santiago, doc. 115.

47 Martín Rodríguez, Orden de Santiago, doc. 174.

48 Rodríguez de Diego, Aguilar, doc. 210. 
IGNACIO ÁLVAREZ BORGE

LA JUSTICIA DEL REY Y EL DESARROLLO DEL PODER MONÁRQUICO EN EL REINADO DE ALFONSO VIII DE CASTILLA (I I 58-I 2 I 4)

Papa y que aceptara que el pleito fuera librado por el rey y su curia, cosa que finalmente aceptó el maestre ${ }^{49}$.

Con frecuencia, antes de que se inicie el proceso judicial propiamente dicho, el rey intenta alcanzar un acuerdo entre las partes. Algunos textos lo reflejan de manera expresa y de otros podemos deducirlo. Quizás el más elocuente sea el que recoge el pleito que enfrentaba hacia 1177 al monasterio de Fitero y al concejo y al señor de Alfaro sobre aprovechamiento de aguas. Como ya hemos indicado, las partes acudieron ante el rey cuando este se encontraba en la zona, en Préjano (La Rioja), y antes de someter el pleito al juicio de la curia quiso el rey que ambas partes llegaran a un acuerdo, pero Lope de Alfaro, señor de ese lugar, se negós0 ${ }^{5}$. Probablemente algo muy parecido podemos encontrar en el acuerdo que alcanzó, ad preces et instanciam domini Aldefonsi regis Castelle et Toleti, el arzobispo de Toledo con la orden de San Juan en 1186 sobre una iglesia en Toledo. O en la conuenienciam confirmada por el rey en 1205 y que había sido realizada también por el arzobispo por orden del rey (rogatus et precepto meo) para resolver el pleito entre el monasterio de Valdeiglesias y los vecinos de ese lugar (San Martín de Valdeiglesias, en Madrid); el resultado fue el documento que es conocido como fuero de Valdeiglesias ${ }^{51}$. Y creo que podemos interpretar en un sentido similar otros documentos relativamente numerosos que recogen pleitos o disputas en los que las partes, según se nos dice, llegaron a acuerdos por orden del rey, o alcanzaron acuerdos en presencia del rey, o incluso otros en los que se dice de forma más genérica que el rey confirmó un acuerdo alcanzado entre las partes ${ }^{52}$. Pero la distancia entre una sentencia tras un juicio propiamente dicho y una concordia establecida por orden del rey por un tercero que actúa, así, como un «juez

49 Hec est memoria de iudiçiis quod habuit magister P. F. cum archiepiscopo de Toleto super illas hereditates de Taiunna quod erant usque in Taio, illas quas fratribus tenebant, et super Alboer. Venit magister noster ad plazo in Toleto et ibi cum archiepiscopo habuit iudicio super istas suprascriptas hereditates et non potuerunt in iudicio illo convenire; et appellavit magister ad archiepiscopum ad Roma, et post appellacionem ad tempus modicum, fuit curata Conca et ante domino rex A. fuit ibi magister, et deprecavit archiepiscopus ad rex ut deprecasset rex ad magister quod istam appellationem solvisset eum et iudicasset rex iudicium istum; et rex deprecavit magistro et placuit magistro quod misissent illum iudicium in manu regis et de sua corte, et remasit istam appellationem per deprecatione quod fecit archiepiscopus dompnus Cerebrunus ad magister P. Fernandi. Martín Rodríguez, Orden de Santiago, doc. 115 y pp. 47-48.

50 García Turza, Monte Laturce, doc. 44.

51 El acuerdo entre el arzobispo y la orden de San Juan en 1186 en GonZÁLez, Alfonso VIII, doc. 455; y el fuero de Valdeiglesias en Ibid., doc. 772. Otro caso similar en Loperráez, Juan. Descripción histórica del obispado de Osma. Madrid: en la Imprenta Real, 1788, vol. 3, doc. 32 de 1195.

52 Ejemplos de lo primero en González, Alfonso VIII, doc. 691 de 1200, doc. 702 de 1201, doc. 729 de 1202, doc. 795 de 1207, doc. 796 de 1207 y doc. 858 de 1210; en Hernández, Cartularios de Toledo, doc. 557 de 1190; y en Ayala Martínez, Carlos de. Libro de privilegios de la Orden de San Juan de Jerusalén en Castilla y León (siglos XII-XV). Madrid: Instituto Complutense de la Orden de Malta, 1995, doc. 205 de 1210.

Ejemplos de lo segundo en González, Alfonso VIII, doc. 448 de 1186, doc. 568 de 1191, doc. 868 de 1210 y doc. 922 de 1214; en Martín Rodríguez, Orden de Santiago, doc. 117 de c 1180; en Hernández, Cartularios de Toledo, doc. 234 de 1190; y en Rivera, Uclés, doc. 65 de 1211.

Ejemplos de lo tercero en González, Alfonso VIII, doc. 809 de 1207, doc. 814 de 1207, doc. 815 de 1207, doc. 818 de 1208, doc. 826 de 1208 y doc. 909 de 1213; en Abajo Martín, Teresa. Documentación de la Catedral de Palencia (1035-1247). Burgos: Ediciones J. M. Garrido Garrido, 1986, doc. 96 de 1185 ; y en Fernández Flórez, José Antonio. Colección diplomática del monasterio de Sahagún (857-1300). Vol. V, 1200-1300. León: Centro de Estudios e Investigación San Isidoro, 1991, doc. 1.552 de 1202. 
árbitro", solo que designado por el rey, no por las partes, debía ser bastante reducida en ocasiones. En 1181 el rey comunicó al prior de la catedral de Toledo el contenido de una concordiam para solucionar las disputas que enfrentaban a la iglesia de Toledo con la orden de Calatrava sobre derechos eclesiásticos. Pero indica el rey que había establecido esa concordia con el obispo de Palencia y el consejo de sus vasallos (Nouerunt quod in presentia mea, assistente Abulensis episcopo, uisum fuit et satis idoneum de consilio uasallorum meorum ad habendam concordiam...). El consilio uasallorum parece referirse a la curia y la intervención del obispo de Palencia recuerda a la de los jueces designados por el rey para resolver determinados $\operatorname{casos}^{53}$.

Pero si el acuerdo no era posible, como refleja el caso del monasterio de Fitero y el concejo de Alfaro, finalmente debía librarse el juicio formalmente. Ante ello, como hemos visto, el rey podía ordenar actuar al merino o, si correspondía que el juicio se librara en la curia, debían actuar los jueces de la curia, jueces designados, extraordinarios, al principio, o jueces permanentes, ordinarios, más adelante. Hemos visto ya varios ejemplos de unos u otros casos ${ }^{54}$.

Podemos agrupar los procedimientos seguidos para librar los pleitos en tres tipos: la realización de pesquisas, que será el procedimiento más frecuente, el análisis y la verificación de pruebas documentales y, en tercer lugar, las ordalías y juramentos. Antes de repasar brevemente cada uno de ellos conviene apuntar que hay un buen numero de documentos que no ofrecen información sobre cuál fue el procedimiento seguido en ese juicio y en algunos otros se puede deducir pero no siempre de forma concluyente.

Cuadro 1. Formas de resolución de los pleitos.

\begin{tabular}{|l|c|}
\hline Pruebas & 5 \\
\hline Ordalías y juramentos & $5(2+3)$ \\
\hline Pesquisas & 34 \\
\hline TOTAL & 44 \\
\hline
\end{tabular}

Solo en 44 de los 88 que ofrecen algún tipo de información sobre pleitos en los que intervino el rey tenemos datos sobre el procedimiento seguido. De ellos, 34 casos fueron resueltos mediante pesquisas, 5 mediante ordalías y juramentos y 5 mediante pruebas documentales. El predominio de las pesquisas en los tribunales regios es, por lo tanto, evidente. Conviene señalar también que, hasta donde hemos podido observar, la aplicación de uno u otro procedimiento no estaba determinada por el tipo de asunto que daba lugar al conflicto. Habría que pensar entonces en la aplicación de los diversos derechos locales.

Comenzaremos revisando las ordalías y los juramentos. Podemos agruparlos en un único bloque por sus evidentes conexiones, aunque también había significativas diferencias.

53 González, Alfonso VIII, doc. 932; y para la fecha y la interpretación del texto, Estepa Díez, "Apéndice I», p. 301.

54 Tampoco faltan documentos que indiquen que el pleito fue librado por la curia regia, pero sin especificar la intervención de jueces concretos. GonZÁLeZ, Alfonso VIII, doc. 429 de 1184, doc. 461 de 1186 o doc. 1034 de 1215, este último ya en el reinado de Enrique I. 
Por lo que se refiere a las ordalías en sentido estricto, solo conocemos dos casos, ambos referidos a duelos o batallas judiciales y ambos también situados en una zona muy delimitada geográficamente: el valle del Najerilla y de su afluente el Cárdenas, en la actual Rioja en las zonas próximas al monasterio de San Millán de la Cogolla.

La información más significativa se contiene en un documento, fechado en 1184, mediante el cual el rey confirma al concejo de Villagonzalo tres majadas que le disputaba el vecino concejo de Madriz (ambos, como he indicado, muy próximos al monasterio de San Millán). En el texto se nos informa de que esa confirmación es consecuencia de un pleito que enfrentaba a ambos concejos por esas majadas, pleito que llegó ante la curia regia donde, en presencia del rey, se ordenó que la disputa se resolviera mediante la lucha entre dos peones en favor de cada uno de los concejos. El concejo cuyo luchador resultara vencedor recibiría las majadas en disputa ${ }^{55}$.

Este documento expresa con toda claridad que la decisión de resolver el pleito mediante un duelo judicial se tomó en la curia regia y, a mi juicio, nos permite interpretar en el mismo sentido o en un sentido muy similar otro texto de $1202 \mathrm{o}$ 1207. Este segundo documento contiene una confirmación de términos al concejo de Pedroso de Río Tobía, que pleiteaba también por cuestiones de términos con los concejos vecinos de Anguiano, Matute, Villanueva y Tobía (todos estos lugares próximos a los anteriores). También ahora se resolvió el pleito mediante una lucha entre peones. Se indica, asimismo, que intervinieron dos pesquisidores que informaron al rey y al merino menor de la zona, Oriol, que fue quien determinó y estableció los términos en disputa, que finalmente fueron confirmados por el rey ${ }^{56}$. No se menciona ahora expresamente la intervención de la curia, pero me parece muy probable a la luz del documento anterior. En cualquier caso, los pesquisidores sí actuaron por orden del rey; fueron el abad de San Millán y el arcediano Sancho de Cárdenas y su papel en este caso no parece ser el de averiguar o determinar los términos -como es muy frecuente en otros casos-, cosa que aquí hizo el merino, sino probablemente supervisar el desarrollo del duelo judicial.

55 Notum sit et manifestum presentibus et futuris quod ego Aldefonsus, Dei gratia rex Castelle et Toleti, iudicium quod subscriptum est inter Villam Gonzalui et Madriz in curia mea iudicari mandaui. Concilium de Villa Gunzalui et concilium de Madriz inter se contentionem habebant super tribus maiadis, scilicet, Pradiella et Cabannas nouas et Losiellas, et illi de Madrid erant tenentes, illi uero de Villa Gunzalui allegabant de iniuria et uilentia sibi illata. Auditis itaque in presentia mea hinc inde allegationibus utriusque partis, datum est illis pro iudicio ut alterutra pars daret unum peditem qui inter se dimicarent, et pars peditis uictoris predictas maiadas iure hereditario perhenniter haberet. Commisso ergo pedestri predio duello deuicit pedes datus a concilio Ville Gonzaluez peditem datum ab illis de Madriz. Inde est quod ego predictus rex Aldefonsus cum uxore mea Alienor regina, facio cartam concessionis et stabilitatis de predictis tribus maiadas uobis toti concilio de Villa Gunzaluez presenti et futuro iure hereditario, uobis habituris in perpetuum, ut in eis scindatis et ganati uestri pascant et ibi iaceant. González, Alfonso VIII, doc. 429.

56 González, Alfonso VIII, doc. 807; Cantera Montenegro, Margarita. Santa María la Real de Nájera. Tesis doctoral, Universidad Complutense de Madrid, 1987, vol. 2, T. 2, doc. 106; García TurZA, Francisco Javier. Documentación medieval del monasterio de Valvanera (siglos XI a XIII). Zaragoza: Anubar, 1985, doc. 228. Las copias del texto que se han conservado presentan algún problema de datación que no detallaré ahora. Solo indicaré que probablemente se trata de un texto falso o interpolado. Sobre ello Álvarez Borge, Cambios y alianzas, pp. 135-136 y nota 10. 
La resolución de conflictos mediante juramentos, aportando un determinado número de juradores que sostengan mediante juramento los argumentos de las partes, también está presente en tres casos. En 1175 o 1185, según ya se ha mencionado, disputaban el monasterio de Cardeña y los hombres de Peñafiel y Fuentidueña sobre la iglesia de Santa María de Cuevas. Hemos visto cómo las partes acudieron a juicio a la curia regia, donde el rey ordenó que el pleito fuera librado por el conde Gómez. El conde dispuso que dos monjes debían jurar los derechos que alegaba el monasterio (que la iglesia les había sido dada tiempo atrás por el conde Asur Fernández). Los monjes lo hicieron y el monasterio recibió sentencia favorable ${ }^{57}$. En 1210 veinte hombres de Olmedo acudieron ante el rey y juraron los derechos que correspondían a los parientes de Vicente Mayor en la iglesia de San Cristóbal de Olmedo y en la heredad de Puras, en el contexto del pleito que sostenían con el monasterio de Silos sobre dichos derechos ${ }^{58}$.

Sobre el procedimiento seguido para prestar los juramentos nos informa con más detalle otro texto al que también hemos aludido ya. Se trata del pleito que tuvo lugar en 1195 entre el monasterio de Albelda y el concejo de Ausejo (en La Rioja) sobre el nombramiento del clérigo a cargo de la iglesia de San Valerio de Ausejo. Como hemos visto, el pleito fue librado en la curia regia por el alcalde del rey García Ruiz. Este determinó que, una vez que los representantes (andadores se les denomina en el texto) del concejo hubieran vuelto a Ausejo (fuerint tornados ad suum concilium), en los tres días siguientes debían nombrar 5 juradores, especificándose que habían de ser 3 sacerdotes y 2 laicos, o bien 3 laicos y 2 sacerdotes, que debían acudir en el plazo de nueve días ante el prior de Calahorra y jurar ante él, sicut consuetudo est iurare, los derechos que alegaba el concejo de Ausejo. Si el concejo no pudiera designar a los juradores en el plazo señalado de tres días, o si estos no realizaran los juramentos en los nueve días siguientes ante el prior, el concejo perdería el juicio (propter hoc cadat concilium Agoseio). Si los juradores del concejo acudieran en el plazo seńalado, pero no fueran capaces de sostener sus derechos mediante juramento, entonces el monasterio debería, a su vez, aportar 3 clérigos juradores que sostuvieran los suyos. En ese caso el monasterio vería reconocidos sus derechos y el concejo debería pagarle el doble de lo que hubiera tomado de la iglesia en disputa ${ }^{59}$.

Plazos y procedimientos nos hablan de un alto grado de ritualización y formalización del proceso judicial. También podemos apreciarlo en otros pleitos resueltos mediante la aportación y validación de pruebas documentales.

En este caso, la expresión más explícita se contiene en el texto que recoge el pleito entre los monasterios de San Juan de Burgos y San Cristóbal de Ibeas de Juarros con el concejo de Santa Cruz de Juarros y sus señores en el episodio que tuvo lugar en 1196. Como hemos visto, las dos partes acudieron por medio de sus voceros ante el rey cuando este se encontraba en Peńafiel y, una vez expuestos sus argumentos, el pleito fue librado por 4 alcaldes regios. Los alcaldes dispusieron que en un plazo de nueve días (de nuevo el mismo plazo que en el caso anterior) el abad y el prior debían volver a la curia regia y mostrar los documentos en los que sostenían sus derechos (afferant coram rege priuilegia

57 Martín Postigo, Santa María de Cárdaba, doc. XIII.

58 GonZÁlez, Alfonso VIII, doc. 863.

59 GonzÁlez, Alfonso VIII, doc. 607. 
sua infra novem dies per manu fidelis). Así lo hicieron, acudiendo de nuevo a la curia, ahora en Valladolid, con los privilegios que fueron leídos ante el rey por el obispo de Osma y, conforme a lo contenido en ellos, recibieron sentencia favorable (et protulerunt priuilegia sua in curia coram rege, et legit ea coram rege dominus Martinus, Oxomensis episcopus, et, secundum quod inuenerunt in priuilegia, iudicauit dominus rex et alcaldi eius) ${ }^{60}$.

De nuevo plazos y procedimientos bien establecidos, que se recogen con detalle en un documento que arroja luz sobre otros menos explícitos. Sabemos que el caso que acabamos de ver en 1196 fue el segundo episodio de un conflicto que ya antes había llegado ante el rey. En 1182 las dos partes enfrentadas ya habían acudido ante el rey en Burgos y este había dispuesto entonces que librara el pleito Lope Díaz de Fitero, el merino mayor. El texto que se conserva es menos detallado, pero nos informa que el merino juzgó también en esa ocasión secundum cartularium (ad horum autem uoces et secundum cartularium iudicauit Lop Diaz) ${ }^{61}$. Seguramente el procedimiento fue similar al que siguieron en 1215 los alcaldes de Toledo don Diego y don Illán en el pleito entre Yepes y Ocaña, que también fue librado conforme a un privilegio de Alfonso VII, aunque el texto, que se conserva solo en copias posteriores, ofrece una versión dialogada del desarrollo del juicio ${ }^{62}$. Y probablemente también fue librado conforme a pruebas documentales el pleito que enfrentaba hacia 1177 al arzobispo de Toledo y a la orden de Santiago sobre heredades en Tajuña y Villamanrique de Tajo. Hemos visto cómo, tras otras vicisitudes, las partes acordaron acudir a juicio ante el rey y la curia regia, donde el rey designó a tres magnates para que libraran el pleito y las partes nombraron a sus voceros. De nuevo se mencionan emplazamientos que deben atender las partes, en este caso para recibir la sentencia. Sabemos que la sentencia fue favorable a la orden y el texto nos informa de la última fase de un pleito de este tipo: la entrega de las heredades disputadas a la parte vencedora mediante un portero del rey. Pero el documento que se ha conservado también indica que la sentencia contenía otra disposición mediante la cual el arzobispo debía entregar un documento, suponemos que aquel en que sostenía sus argumentos, que quedaría en manos del rey y se nos indica, asimismo, que el juicio fue juzgado mediante los documentos presentados por las partes (et per manu portarium regis acceperunt fratres istam hereditatem et de manu regis, et illa carta quod inde tenebat archiepiscopo misit in manu regis et per istas cartas fuit suprascriptum iudicium iudicatum $)^{63}$. Me parece probable, aunque no puedo asegurarlo con certeza, que el pleito entre el concejo de Sepúlveda y el obispo de Segovia, que fue librado por el rey y sus iudicibus curiae en 1196, también fuera librado atendiendo a lo contenido en los documentos aportados por las partes. No se indica expresamente en el texto que se conserva, pero los argumentos expuestos por los contendientes me llevan a pensarlo ${ }^{64}$.

60 González, Alfonso VIII, doc. 653; y Peña Pérez, San Juan, doc. 58.

61 Peña Pérez, San Juan, doc. 43.

62 Hernández, Cartularios de Toledo, doc. 360. El texto, que se conserva copiado en dos cartularios de la catedral de Toledo elaborados ańos más tarde, indica que el juicio se celebró en marzo de 1215 por orden del rey Enrique I, pero los alcaldes habían comenzado a librar el pleito con anterioridad y por orden del rey Alfonso VIII.

63 Martín Rodríguez, Orden de Santiago, doc. 115.

64 González, Alfonso VIII, doc. 1029. 
IGNACIO ÁLVAREZ BORGE

LA JUSTICIA DEL REY Y EL DESARROLLO DEL PODER MONÁRQUICO EN EL REINADO DE ALFONSO VIII DE CASTILLA (I I 5 8-I 2 I 4)

Pero la mayor parte de los pleitos fueron resueltos mediante la realización de pesquisas $^{65}$. Aunque los documentos también son muy desiguales en la información que proporcionan en estos casos, igualmente podemos ver que los procedimientos estaban bien establecidos y formalizados.

Primero, el nombramiento de los pesquisidores, entre los que no es raro que se encuentren los merinos mayores y menores en pleitos al norte del Duero ${ }^{66}$. Aunque el número es variable, frecuentemente serán dos o tres, a menudo siendo al menos uno de ellos eclesiástico, aunque no siempre. No es raro que en ciertas zonas se repita algún individuo actuando como pesquisidor en varios casos, de manera que podría haber una cierta continuidad y especialización. En una ocasión se documenta también un oficial específico designado como pesquisidor del rey en un territorio; se trata de Martín Pérez de Boeza, quien en el escatocolo de un documento de Piasca de 1212 figura como Pesquisidor del rey en toda La Liéban [a $]^{67}$. De esa manera podríamos pensar que otros personajes que actúan como pesquisidores con cierta frecuencia (el prior de Piasca y Rodrigo Pérez de Baró en la zona de Liébana en los años 80 y 90; el arcediano Sancho de Cárdenas en La Rioja hacia finales del siglo xII y comienzos del XIII) también pudieron ser oficiales regios con esa función. Pudiera haber, así, un cuerpo específico de pesquisidores regios (o haberlo en algún momento), pero la única referencia clara es la de Martín Pérez de Boezo en Liébana en 1212 y, por el contrario, muchos otros pesquisidores parecen haber sido designados para cada caso concreto.

Hemos de suponer que serían elegidos por su conocimiento de las realidades y las normas y fueros locales. Además de la presencia de clérigos, algunos textos, especialmente entre los referidos a zonas al norte del Duero, destacan su pertenencia a la nobleza, pero no parece que fuera una condición necesaria. Cuando el monasterio de Sahagún acudió al rey en 1188 para recuperar unas heredades que había perdido en Valladolid, el rey designó a 4 hombres viejos y honrados para que hicieran una pesquisa y averiguaran la verdad (quatuor senibus et probis hominibus de Valdeolit) ${ }^{68}$. En alguna ocasión, también los alcaldes de importantes concejos como Burgos o Toledo actuaron como pesquisidores ${ }^{69}$.

65 Sobre las pesquisas, además de los trabajos clásicos como Cerdé Ruiz-Funes, Joaquín. «En torno a la pesquisa y procedimiento inquisitivo en el derecho castellano-leonés de la Edad Media». Anuario de Historia del Derecho Español, 1962, vol. 32, pp. 483-518; o Procter, Evelyn S. El uso judicial de la pesquisa en León y Castilla (1157-1369). Granada: Instituto de Historia del Derecho, 1978; véase ahora Alfonso, Isabel y Jular, Cristina. «Ońa contra Frías o el pleito de los cien testigos. Una pesquisa en la Castilla del siglo XIII". Edad Media. Revista de Historia, 2000, vol. 3, pp. 61-88; y Alfonso, Isabel. "Memoria e identidad en las pesquisas judiciales en el área castellano-leonesa medieval». En JARA, José Antonio; Martin, Georges y Alfonso, Isabel (eds.). Construir la identidad en la Edad Media. Poder y memoria en la Castilla de los siglos VII a XV. Cuenca: Ediciones de la Universidad de Castilla-La Mancha, 2010, pp. 249-279.

66 Algunas referencias a ellos en Álvarez Borge, Clientelismo regio, pp. 103-110, 144-146 y 161-165.

67 Montenegro Valentín, Julia. Colección diplomática de Santa María de Piasca (857-1252). Santander: Consejería de Cultura, Educación, Juventud y Deporte, 1991, doc. 158.

68 González, Alfonso VIII, doc. 508; y Fernández Flórez, José Antonio. Colección diplomática del monasterio de Sahagún (857-1300).Vol. IV, 1110-1199. León: Centro de Estudios e Investigación San Isidoro, 1991, doc. 1443.

69 Alcaldes de Burgos en Peña Pérez, San Juan, doc. 60 de c 1200; alcaldes de Toledo en GonzÁlez, Alfonso VIII, doc. 766 de 1204. 
Una vez designados, los pesquisidores realizan la pesquisa o averiguación tomando testimonio mediante juramento a testigos del lugar o lugares del conflicto o de las villas próximas. Las uillas fazeras, las circumiacentibus uillis que sunt in facie de aquella donde se desarrollaba el conflicto, o las villas frontariiis ${ }^{7}$. De esos lugares se tomaba un número variable de testigos que debían expresar su testimonio bajo juramento (fecerunt iurare supra quatuor euangelia que dixissent ueritatem $)^{71}$. La elección de quienes habían de expresar su testimonio debía ser un factor clave para resolver el conflicto en un sentido o en otro. Los textos se refieren a ellos con un sentido retórico como «hombres veraces» (ueridicos uiros), «los mejores del concejo» (melioribus concilii), sabidores, «ancianos y honrados» (senibus et probis) $\mathrm{u}$ «hombres buenos» (bonis uiris o bonos homines) ${ }^{72}$. Con frecuencia los documentos recogen el nombre de los que prestaron su testimonio y su lugar de procedencia.

Una vez averiguada la verdad mediante la pesquisa, se dictaba la sentencia, sea por el merino, el alcalde (o los alcaldes) del rey o el propio monarca. Cuando los pleitos lo son por términos y pastos o por heredades concretas el final del proceso consiste en la delimitación física de esos términos o en la entrega de las heredades disputadas. Con frecuencia en ambos actos intervienen los merinos, a menudo en compañía de otros oficiales específicos, los porteros (porteros del rey o, en ocasiones, porteros de los merinos).

Pero no se llevaron a cabo pesquisas solo en relación con términos y heredades, sino también en pleitos por otros asuntos diversos. Los resumo en el cuadro siguiente:

Cuadro 2. Tipos de pleitos que se resuelven mediante pesquisas.

\begin{tabular}{|l|c|}
\hline Términos & 13 \\
\hline Heredades & 9 \\
\hline Derechos (rentas, fueros) & 6 \\
\hline Aguas (presas, aprovechamiento) & 4 \\
\hline Iglesias & 1 \\
\hline Varios & 1 \\
\hline TOTAL & 34 \\
\hline
\end{tabular}

Como he indicado más arriba, a la luz de los documentos, el proceso de realización de pesquisas estaba bien formalizado y establecido en el reinado de Alfonso VIII. Parece

70 Véase respectivamente Rodríguez de Diego, Aguilar, doc. 49 de 1182; González, Alfonso VIII, doc. 406 de 1183; o SÁnchez Belda, Luis. Cartulario de Santo Toribio de Liébana. Madrid: Patronato Nacional de Archivos Históricos, 1948, doc. 125 de 1197, entre otros documentos donde se encuentran esas expresiones $\mathrm{u}$ otras equivalentes.

71 Rodríguez de Diego, Aguilar, doc. 49 de 1182. Otras referencias expresas de la testificación bajo juramento en GonzÁLez, Alfonso VIII, doc. 406 de 1183, doc. 660 de 1197, doc. 751 de 1203, doc. 905 de 1213 o doc. 934 de 1206-1211 (fecha corregida por Estepa Díez, «Apéndice I», p. 305.

72 Esas expresiones, por el orden en que las he mencionado, en GonZÁLEZ, Alfonso VIII, doc. 290 de 1177, doc. 294 de 1178; Rodríguez de Diego, Aguilar, doc. 49 de 1182; González, Alfonso VIII, doc. 508 de 1188; Ruiz de Loizaga, Saturnino. El libro Becerro de Santa María de Bujedo de Candepajares (11681240). Miranda de Ebro: Fundación Cultural Profesor Cantera Burgos, 2000, doc. 64 de 1183 o 1193; SÁnchez Belda, Santo Toribio, doc. 125 de 1197; y González, Alfonso VIII, doc. 751 de 1203. 
IGNACIO ÁLVAREZ BORGE

LA JUSTICIA DEL REY Y EL DESARROLLO DEL PODER MONÁRQUICO EN EL REINADO

DE ALFONSO VIII DE CASTILLA (I I 5 8-I 2 I 4)

seguirse un procedimiento previamente fijado que he intentado resumir brevemente. Un procedimiento que, además, se expresaba mediante textos escritos. Me referiré a ello a continuación, porque creo que merece una reflexión algo más detenida.

\section{El PAPEL De lo ESCRITO y LO Leído}

Más arriba hemos visto cómo algunos pleitos se resolvieron acudiendo a pruebas documentales. Distan de ser mayoritarios, pero sí son un número significativo de casos. Ahora me interesa fijarme en otro aspecto, para subrayar que la mayor formalización del proceso judicial, a la que he aludido en las páginas anteriores, pasaba por un mayor papel de los documentos y que algunos de ellos tenían como finalidad ser leídos en público. Reflexionaremos, entonces, sobre lo escrito y lo leído.

En primer lugar, el nombramiento de los pesquisidores y la orden a los pesquisidores para que realizaran la pesquisa se hacía por carta. Ninguna de ellas se ha conservado directamente, al menos hasta donde yo sé, pero sí hay referencias en otros documentos. En 1186 el deán y un canónigo de Toledo tomaron posesión de la aldea de Santa María de Cortes, que les fue entregada por un portero regio por orden del rey. Les entregó la aldea y sus términos según fueron establecidos por varios pesquisidores que habían sido designados por el rey según se contenía en cartas del rey que habían sido vistas y oídas por los testigos de la entrega: per litteras suas (del rey) quam nidimus et audiuimus ${ }^{73}$. Por lo tanto, los pesquisidores habían recibido cartas del rey y las habían mostrado, se habían leído públicamente, para exponer sin género de dudas que actuaban en nombre del rey. Años más tarde Alfonso VIII ordenó también por carta a los alcaldes de Toledo don Diego y Esteban Illán que establecieran los términos entre Ocaña y Yepes: El rei don Alfonso, que Dios perdone, enbio su carta a alcaide don Diado e a don Illan el alcalde, que fuessemos departir el termino de Yepes e de Occanna ${ }^{74}$.

Una vez realizada, la pesquisa es puesta por escrito señalando con detalle, como he indicado, el nombre y procedencia de los testigos y en ocasiones su condición, así como el contenido de su declaración. De manera que la actuación de los pesquisidores daba lugar a un documento que se enviaba al rey. De nuevo lo que conservamos con mayor frecuencia no son esos pergaminos estrictamente, sino su copia más o menos literal e inserción en otros documentos, frecuentemente en las posteriores sentencias y disposiciones regias. Pero antes de eso el documento con la pesquisa era remitido al rey y en la corte era abierta y leída en presencia del rey y, según señala expresamente algún documento, en presencia también de algún testigo. Por eso, además de abrir la pesquisa, esta se leía en voz alta.

El envío del documento de la pesquisa queda recogido, por ejemplo, en 1204, cuando el rey indica que los pesquisidores que había nombrado en relación con una disputa sobre el pago de portazgos en el Tajo le comunicaron el resultado en un documento:

73 Hernández, Cartularios de Toledo, doc. 216, y tomo la cita de la copia que se conserva en el Becerro de la Catedral de Toledo, en AHN, Códices, 996, fol. 79r.

74 Hernández, Cartularios de Toledo, doc. 360. 
Et significauerunt mibi (al rey) per cartam suam... ${ }^{75}$. Cartam que, por lo que nos indican otros textos, fue abierta, leida o recitada en presencia del rey. En 1182 el rey confirmó una pesquisa que había ordenado y que eam ante me recitauerunt ${ }^{76}$. El año siguiente, el merino mayor envió al rey la pesquisa que había realizado sobre Arroyal, pesquisa que fue coram domino rege Aldefonso relata et recitata ${ }^{77}$. Y años después otro ejemplo contribuye a iluminar también esta fase del proceso. En 1203 pleiteaban el monasterio de Carrión y los hombres de Nogal de las Huertas sobre una presa en un canal derivado del río Carrión. El rey, como en tantos casos, ordenó realizar una pesquisa, en esta ocasión al abad de Sahagún y a Rodrigo Martínez, quienes enviaron la pesquisa al rey. En este caso el texto que se conserva nos informa de que el documento de la pesquisa, el pergamino que la contenía, fue abierto en presencia del rey y del arzobispo de Toledo (soluta hac pesquisa ante me [el rey] et ante domnum Martinum, Toletanum archiepiscopum $)^{78}$.

De estos documentos podemos deducir la importancia de que las pesquisas se hicieran públicas en el ámbito de la corte, especificándose incluso en ocasiones el nombre de los presentes, para garantizar que las subsiguientes sentencias se adecuaban a la verdad averiguada mediante las pesquisas.

Porque a la luz de las pesquisas el rey o sus alcaldes o los merinos dictaban sentencia. Y la sentencia también implicaba otros documentos. Documentos para las partes enfrentadas en los pleitos y documentos también para los oficiales regios, merinos y porteros, que debían ejecutar materialmente las sentencias. Estos también recibían documentos, cartas, que debían ser escritos... y leídos públicamente.

El pleito de la presa de Nogal, al que acabamos de referirnos, terminó con la realización de tres documentos conteniendo la sentencia (que, por cierto, fue favorable al monasterio y por eso se ha conservado): uno para el monasterio de San Zoilo, otro para el monasterio de Sahagún, señor de Nogal, y otro que debía quedar en manos del rey (et istam pesquisam sicut ante me soluta est approbo, roboro et confirmo et, ut monasterio beati Zoyli perpetuo ualeat, tres cartas inde fieri precepi, quarum unam ego habeo, aliam in monasteriio Sancti Facundi mandaui reseruari, tercia uero Sancto Zoylo ${ }^{79}$. Pero, además, el rey indica que había ordenado a su portero que destruyera la presa en cuestión y que lo hiciera en presencia del abad de Sahagún ${ }^{80}$.

Esta fase, la ejecución material de la sentencia, daba lugar también a documentos independientes de los que se han conservado pocos casos, aunque sí hay algunas noticias suficientemente significativas.

75 González, Alfonso VIII, doc. 766.

76 González, Alfonso VIII, doc. 398.

77 GonzÁlez, Alfonso VIII, doc. 406.

78 González, Alfonso VIII, doc. 751; y Pérez Celada, Julio Antonio. Documentación del monasterio de San Zoilo de Carrión (1047-1300). Burgos: Garrido Garrido, 1986, doc. 72. Sobre este asunto, Pérez CELADA, Julio Antonio. "La explotación de los recursos hidráulicos en el curso medio del río Carrión en la Edad Media». Publicaciones de la Institución Tello Téllez de Meneses, 2000, vol. 71, pp. 113-134, especialmente pp. 120-121.

79 González, Alfonso VIII, doc. 751; y Pérez Celada, San Zoilo, doc. 72.

80 Dedi portarium meum qui crebrantaret illam presam de Nogar, presente et asistente et uidente domno Pelagio, abbate Sancti Facundi, quando illam presam crebrantaret. Ibid. 
IGNACIO ÁLVAREZ BORGE

LA JUSTICIA DEL REY Y EL DESARROLLO DEL PODER MONÁRQUICO EN EL REINADO

DE ALFONSO VIII DE CASTILLA (I I 5 8-I 2 I 4)

El monje (o monjes) que compuso el cartulario del monasterio de Santa María de Aguilar de Campoo, conocido como el Becerro de Aguilar, copió dos curiosas noticias. En ellas se da cuenta de dos pleitos, uno que mantenía el monasterio de Aguilar con el concejo de Aguilar (los de Aguilar) sobre una presa, y otro del concejo de Aguilar con el concejo de Valberzoso (unos km al norte de Aguilar) sobre un monte. En ambos casos el rey había ordenado realizar sendas pesquisas como resultado de las cuales ordena, en el primer caso, que se deshaga la presa sobre la que se pleiteaba y, en el segundo caso, que ambas partes puedan aprovechar el monte. Lo significativo es que las noticias que se conservan se refieren a la orden que dio el rey a su merino Gonzalo Miguel (seguramente el merino de Aguilar) para que, acompañado por el portero del rey, ejecutara las sentencias. Pero el rey ordena que lo haga a la vista de las pesquisas que dice que incluye también en las cartas que le envía selladas con su sello (istam pesquisa quam uidere potestis in ista carta quam mitto uobis sub meo sigillo ${ }^{81}$.

Por lo tanto, el rey designaba a los pesquisidores mediante documentos, estos le remitían el resultado de las pesquisas también consignadas por escrito en documentos que enviaban a la corte, donde eran abiertos y leídos públicamente ante el rey. El rey comunicaba la sentencia a las partes de nuevo en documentos en los que frecuentemente se copiaba la pesquisa, elaborándose varios y permaneciendo uno de ellos en la cancillería regia. Pero se elaboraban también otros documentos, en los que se podía incluir asimismo la pesquisa, comunicando a los oficiales regios lo que debían hacer para ejecutar materialmente la sentencia. Un proceso en el que interviene una burocracia bastante desarrollada. Más de lo que quizás se pudiera pensar. $\mathrm{Y}$ un proceso que conocemos mal porque carecemos de los registros de la cancillería regia. Solo podemos reconstruirlo a partir de las piezas fragmentadas del puzle que se conservan en la documentación privada. Piezas, además, manipuladas al transcribirlas en cartularios cuando y como interesaba a los monjes de unos u otros monasterios. Se copiaban las sentencias favorables, casi nunca las desfavorables; se resumían y refundían los documentos porque, en definitiva, el objetivo no era copiar los textos fielmente sino garantizar derechos. Pero, aunque lo que se conserva son piezas fragmentadas, sí creo que son suficientes y suficientemente elocuentes para mostrar el desarrollo burocrático en la administración de la justicia del rey en el reinado de Alfonso VIII.

Un desarrollo sustentado en documentos que se escribían para garantizar derechos y propiedades y cuya finalidad con cierta frecuencia no solo era ser guardados y conservados, sino primero ser leídos públicamente, precisamente para garantizar mejor esos derechos.

81 Aldefonsus, Dei gratia rex Castelle, Gonzaluo Micaelis, merino, salutem. Sciatis quod pro illa contenda quam habebant los de Aguilar cum abbate Sancte Marie de Aguilar super illa presa, mandaui illa pesquirere et inueni ego istam pesquisam quam uidere potestis in ista carta quam mitto uobis sub meo sigillo. Unde mando uobis firmiter quod statim, uisis litteris, faciatis cum isto meo portario defacere illam presam quam fecerunt homines de Aguilar de nouo quousque ego exeam ad ipsam terram. Et non faciatis inde aliud pro quanto uos amatis.

De magis sciatis quod, pro illa contenda quam habebant los de Aguilar cum los de Valuerzoso super monte, mandani ego pesquirere et inueni istam pesquisam quam uidere potestis in ista carta quam mitto uobis sub meo sigillo. Unde mando uobis firmiter quod sicut pesquisa dicit, cum isto meo portario faciatis illud compleri, quod habeant illud de communi et nichil sit ibi departido. GonzÁLez, Alfonso VIII, doc. 914; y Rodríguez DE Diego, Aguilar, doc. 256. 
Las pesquisas, como hemos visto, se leían en voz alta en la corte, se recitaban según la expresión de algún documento, y las órdenes del rey a sus oficiales para que ejecutaran las sentencias también eran leídas en público en los lugares y ante las gentes afectadas.

Un último ejemplo puede servir para resumir todo el proceso. En el monasterio de San Zoilo de Carrión se realizó a comienzos del siglo XIII un cuaderno o pequeño cartulario en el que se copiaron varios documentos; entre ellos uno que contiene una disputa que tuvo lugar entre 1206 y 1211 entre los de Gańinas y los de Riotorto, ambos lugares en la zona de Saldaña en Palencia ${ }^{82}$. Gañinas pertenecía al monasterio de San Zoilo y Riotorto a los Bueso, a Pedro Bueso y a María Bueso, miembros de una familia de la nobleza de la zona vinculada con los Girón. En realidad se trata de dos disputas, pero relacionadas entre sí. Por un lado, los de Gañinas y los de Riotorto disputaban por términos y derechos de pastos. Por otro lado, se disputaba también por un cauce que había ordenado construir María Bueso y que afectaba a los de Gañinas (ambos lugres estaban en la vega del río Carrión, entre Saldaña y Carrión, de forma que el cauce seguramente limitaba o reducía el agua que llegaba a Gañinas). La disputa llegó al rey, quien ordenó realizar dos pesquisas, una la encomendó al abad de Benevívere y a dos caballeros de la zona (milites), Álvaro Nazareno y Fernando Núñez; la otra al mismo abad de Benevívere, al prior de Nogal y al merino del rey en Saldańa (el merino menor) Diego Íńiguez. Ambos grupos realizaron sus pesquisas, que enviaron por escrito al rey en litteras illorum sigillatas mediante un canónigo de Benevívere, cuando el rey se encontraba en Valladolid. En el documento que se conserva se transcribió el contenido de esas pesquisas, pero modificándolo como si fuera una única pesquisa, cuando sabemos que hubo dos asuntos, dos grupos de pesquisidores y el plural litteras es perfectamente elocuente.

Las cartas fueron vistas y oídas por el rey, poniéndose de relieve de nuevo la lectura pública de los documentos, quien aceptó su contenido ordenando que se pusiera su sello sobre ellas (fecit eas in sigillo suo includi cum quibusdam aliis litteris suis). A continuación el rey ordenó que las cartas conteniendo las pesquisas, y ahora selladas con el sello del rey, fueran enviadas al merino de Saldaña para que fuera a Gañinas e hiciera que se cumpliera lo dispuesto en ellas (et misit eas Didago, merino suo de Saldania, precipiens ei firmiter quatenus omni occasione et dilatione remota, accederet ad Ganninas et faceret omnia integrari iuxta tenore karte sibi trasmise). Recibidas las cartas y abierto el sello del rey, el merino las hizo leer públicamente en Saldaña in pleno foro (Idem ergo (sic) Didacus merinus recepit predictum mandatum regis ab Saldaniam, et, aperto sigilo regis, fecit litteras illas legi in pleno foro). Hecho esto, al día siguiente el merino fue a Gañinas y, en presencia de muchos hombres buenos ordenó que se cumpliera el mandato del rey (coram multis bonis hominibus mandatum regis compleuit). Ordenó deshacer el cauce y dividió los términos en disputa, estableciéndolos como estaban cuando Gañinas pertenecía al rey, antes de que este la diera al monasterio en un cambio de heredades.

82 González, Alfonso VIII, T. 3, doc. 934; Pérez Celada, San Zoilo, doc. 68 y pp. XXXI-XXXII sobre el manuscrito que este autor denomina "Cuaderno de copias de documentos»; y PÉrEz RodríGUEz, Estrella. «Vita Didaci». Poema sobre el fundador de Benevivere. Estudio y edición critica con traducción del poema y de los diplomas relacionados. León: Universidad de León, 2008, doc. C.37. Pero véase la fecha que propone EsTEPA Díez, «Apéndice I», p. 305. 
IGNACIO ÁLVAREZ BORGE

LA JUSTICIA DEL REY Y EL DESARROLLO DEL PODER MONÁRQUICO EN EL REINADO

DE ALFONSO VIII DE CASTILLA (I I 5 8-I 2 I 4)

Burocracia y documentos para garantizar la justicia del rey. Una parte de esa garantía se obtenía mediante su lectura pública, fuera en la corte regia, fuera in pleno foro en Saldaña o en cualquier otro lugar.

\section{Conclusiones}

En las páginas anteriores he intentado mostrar cómo durante el reinado de Alfonso VIII el ejercicio de la justicia del rey alcanza un nuevo desarrollo. Frente a la expansión de los poderes señoriales, dotados de atribuciones en materia de justicia (dominio señorial), el rey se dota de instrumentos y medios para hacer efectiva y ejercer su superioridad jurisdiccional (señorio jurisdiccional regio). Instrumentos y medios en forma de oficiales específicos, como los merinos mayores y sus oficiales dependientes los merinos menores o los alcaldes de la curia. Pero también confiriendo al proceso judicial un mayor grado de formalización y burocratización, en lo que tendrá una importancia cada vez mayor la realización de documentos: cartas, que con frecuencia se escribían para ser leídas públicamente, dando a conocer y haciendo así más efectiva la justicia del rey.

Este desarrollo de la justicia del rey forma parte de un proceso más amplio de extensión del poder real (siguiendo la terminología de Carlos Estepa) que, afectando a múltiples campos (desde la fiscalidad a la acuńación de moneda), es bien apreciable ya en el reinado de Alfonso VIII.

REFERENCIAS BIBLIOGRÁFICAS

Abajo Martín, Teresa. Documentación de la Catedral de Palencia (1035-1247). Burgos: Ediciones J. M. Garrido Garrido, 1986.

Alfonso Antón, Isabel. "Judicial rethoric and political legitimation in medieval León-Castile». En Alfonso, Isabel; Kennedy, Hugh y Escalona, Julio (eds.). Building legitimacy. Political discourses and forms of legitimation in medieval societies. Leiden: Brill, 2004, pp. 51-87.

Alfonso, Isabel y Jular, Cristina. «Oña contra Frías o el pleito de los cien testigos. Una pesquisa en la Castilla del siglo xiII». Edad Media. Revista de Historia, 2000, vol. 3, pp. 61-88.

Alfonso, Isabel. "Memoria e identidad en las pesquisas judiciales en el área castellano-leonesa medieval». En Jara, José Antonio; Martin, Georges y Alfonso, Isabel (eds.). Construir la identidad en la Edad Media. Poder y memoria en la Castilla de los siglos VII a XV. Cuenca: Ediciones de la Universidad de Castilla-La Mancha, 2010, pp. 249-279.

Álvarez Borge, Ignacio. Cambios y alianzas. La politica regia en la frontera del Ebro en el reinado de Alfonso VIII de Castilla (1158-1214). Madrid: Consejo Superior de Investigaciones Científicas, 2008.

Álvarez Borge, Ignacio. Clientelismo regio y acción política. Los merinos mayores de Castilla en el reinado de Alfonso VIII (1158-1214). Madrid: Sociedad Espańola de Estudios Medievales, 2014.

Álvarez Borge, Ignacio. Monarquía feudal y organización territorial. Alfoces y merindades en Castilla (siglos X-XIV). Madrid: Consejo Superior de Investigaciones Científicas, 1993.

Ayala Martínez, Carlos de. Libro de privilegios de la Orden de San Juan de Jerusalén en Castilla y León (siglos XII-XV). Madrid: Instituto Complutense de la Orden de Malta, 1995. 
IGNACIO ÁLVAREZ BORGE

LA JUSTICIA DEL REY Y EL DESARROLLO DEL PODER MONÁRQUICO EN EL REINADO DE ALFONSO VIII DE CASTILLA (I I 58 -I 2 I 4 )

Berganza, Francisco de. Antigüedades de España. En Madrid: por Francisco del Hierro, 1721.

Bianchini, Janna. «The distribution of tenancies in León, c. 1200-1250: charter evidence for a history of power». Journal of Medieval Iberian Studies, 2013, vol. 5/1, pp. 33-46.

Calderón Ortega, José Manuel. «La justicia en Castilla y León durante la Edad Media». En La administración de justicia en la Historia de España. Guadalajara: Junta de Comunidades de Castilla-La Mancha, 1999, vol. 1, pp. 21-38.

Cantera Montenegro, Margarita. Santa María la Real de Nájera. Tesis doctoral, Universidad Complutense de Madrid, 1987.

Cerdá Ruiz-Funes, Joaquín. «En torno a la pesquisa y procedimiento inquisitivo en el derecho castellano-leonés de la Edad Media». Anuario de Historia del Derecho Español, 1962, vol. 32, pp. $483-518$.

Estepa Díez, Carlos. «Apéndice I. Nuevos diplomas de Alfonso VIII. Corrección y atribución de fechas. Nota sobre documentos falsos y sospechosos». En Estepa, Carlos; Álvarez, Ignacio y Santamarta, José María. Poder real y sociedad. Estudios sobre el reinado de Alfonso VIII (11581214). León: Universidad de León, 2011, pp. 271-308.

Estepa Díez, Carlos. «El reino de Castilla de Alfonso VIII (1158-1214)». En Estepa, Carlos; Álvarez, Ignacio y Santamarta, José María. Poder real y sociedad. Estudios sobre el reinado de Alfonso VIII (1158-1214). León: Universidad de León, 2011, pp. 11-63.

Estepa Díez, Carlos. «La construcción de la fiscalidad real». En Estepa, Carlos; Álvarez, Ignacio y Santamarta, José María. Poder real y sociedad. Estudios sobre el reinado de Alfonso VIII (1158-1214). León: Universidad de León, 2011, pp. 65-94.

Estepa Díez, Carlos. "La monarquía castellana en los siglos XiII-XIV. Algunas consideraciones». Edad Media. Revista de Historia, 2007, vol. 8, pp. 79-98.

Estepa Díez, Carlos. «Las limitaciones del poder universal: el imperio y las monarquías feudales». En López OJeda, Esther (coord.). 1212, un año, un reinado, un tiempo de despegue. Logroño: Instituto de Estudios Riojanos, 2013, pp. 15-38.

Estepa Díez, Carlos. «Sobre los orígenes de los merinos mayores en León y Castilla». En Mínguez, José María y Ser, Gregorio del (eds.). La Peninsula en la Edad Media. Treinta años después. Estudios dedicados a José Luis Martín. Salamanca: Ediciones Universidad de Salamanca, 2006, pp. $87-100$.

Fernández Flórez, José Antonio. Colección diplomática del monasterio de Sahagún (857-1300). Vol. IV, 1110-1199. León: Centro de Estudios e Investigación San Isidoro, 1991.

Fernández Flórez, José Antonio. Colección diplomática del monasterio de Sahagún (857-1300). Vol. V, 1200-1300. León: Centro de Estudios e Investigación San Isidoro, 1991.

García de Cortázar, José Ángel. «El reinado de Alfonso VIII en el proceso de configuración constitucional del reino de Castilla». En Baró, Juan y Serna, Margarita (eds.). El fuero de Laredo en el octavo centenario de su concesión. Santander: Universidad de Cantabria, 2001, pp. 127-150.

García de Cortázar, José Ángel; Munita, José Antonio y Fortún, Luis Javier. Codiphis. Catálogo de colecciones diplomáticas hispano-lusas de época medieval. Santander: Fundación Marcelino Botín, 1999.

García Turza, Francisco Javier. Documentación medieval del monasterio de San Prudencio de Monte Laturce (siglos X-XV). Logroño: Instituto de Estudios Riojanos, 1992,

García Turza, Francisco Javier. Documentación medieval del monasterio de Valvanera (siglos XI a XIII). Zaragoza: Anubar, 1985.

Garrido Garrido, José Manuel. Documentación de la catedral de Burgos (1184-1222). Burgos: Ediciones J. M. Garrido Garrido, 1983. 
IGNACIO ÁLVAREZ BORGE

LA JUSTICIA DEL REY Y EL DESARROLLO DEL PODER MONÁRQUICO EN EL REINADO

DE ALFONSO VIII DE CASTILLA (I I 5 8-I 2 I 4 )

González, Julio. El reino de Castilla en la época de Alfonso VIII. Madrid: Escuela de Estudios Medievales, 1960, 3 vols.

Guglielmi, Nilda. «La curia regia en León y Castilla (I)». Cuadernos de Historia de España, 1955, vol. 23-24, pp. 116-267.

Hernández, Francisco Javier. Los cartularios de Toledo. Catálogo documental. Madrid: Fundación Ramón Areces, 1985.

Loperráez, Juan. Descripción histórica del obispado de Osma. Madrid: en la Imprenta Real, 1788.

Martín Postigo, María de la Soterraña. Santa María de Cárdaba. Priorato de Arlanza y granja de Sacramenia. Valladolid: Secretariado de Publicaciones de la Universidad de Valladolid, 1979.

Martín Rodríguez, José Luis. Orígenes de la orden militar de Santiago (1170-1195). Barcelona: Consejo Superior de Investigaciones Científicas, 1974.

Martínez Díez, Gonzalo. Alfonso VIII rey de Castilla y de Toledo. Burgos: La Olmeda, 1995.

Martínez Díez, Gonzalo. Fueros locales en el territorio de la provincia de Burgos. Burgos: Caja de Ahorros Municipal de Burgos, 1982.

Montenegro Valentín, Julia. «Algunas consideraciones sobre los orígenes del merino mayor». Anuario de Historia del Derecho Español, 1997, vol. 67, pp. 1091-1106.

Montenegro Valentín, Julia. Colección diplomática de Santa María de Piasca (857-1252). Santander: Consejería de Cultura, Educación, Juventud y Deporte, 1991.

Peńa Pérez, Francisco Javier. Documentación del monasterio de San Juan de Burgos (1091-1400). Burgos: Ediciones J. M. Garrido Garrido, 1983.

Pérez Celada, Julio Antonio. «La explotación de los recursos hidráulicos en el curso medio del río Carrión en la Edad Media». Publicaciones de la Institución Tello Téllez de Meneses, 2000, vol. 71, pp. 113-134.

Pérez Celada, Julio Antonio. Documentación del monasterio de San Zoilo de Carrión (10471300). Burgos: Garrido Garrido, 1986.

Pérez Rodríguez, Estrella. «Vita Didaci». Poema sobre el fundador de Benevivere. Estudio y edición critica con traducción del poema y de los diplomas relacionados. León: Universidad de León, 2008.

Prieto Morera, Agustín. «El proceso en el reino de León a la luz de los diplomas». En El reino de León en la Alta Edad Media, vol. II. Ordenamiento jurídico del reino. León: Centro de Estudios e Investigación San Isidoro, 1992, pp. 381-518.

Procter, Evelyn S. El uso judicial de la pesquisa en León y Castilla (1157-1369). Granada: Instituto de Historia del Derecho, 1978.

Rivera Garretas, Milagros. La encomienda, el priorato y la villa de Uclés en la Edad Media (11741310). Madrid: Consejo Superior de Investigaciones Científicas, 1985.

Rodríguez de Diego, José Luis. Colección diplomática de Santa María de Aguilar de Campoo (852-1230). Valladolid: Junta de Castilla y León, Consejería de Cultura y Turismo, 2004.

Rodríguez de Lama, Inocencio. Colección diplomática medieval de La Rioja. Logroño: Instituto de Estudios Riojanos, 1979, 3 vols.

Ruiz de Loizaga, Saturnino. El libro Becerro de Santa María de Bujedo de Candepajares (11681240). Miranda de Ebro: Fundación Cultural Profesor Cantera Burgos, 2000.

Sáinz Ripa, Eliseo. Colección diplomática de las colegiatas de Albelda y Logroño (Tomo I: 924-1399). Logroño: Comunidad Autónoma de La Rioja, 1981.

SÁnchez Belda, Luis. Cartulario de Santo Toribio de Liébana. Madrid: Patronato Nacional de Archivos Históricos, 1948.

SÁnchez-Albornoz, Claudio. La curia regia portuguesa. Siglos XII y XIII. Madrid: Centro de Estudios Históricos, 1920.

SÁnChez-Arcilla, José. La administración de justicia real en León y Castilla (1252-1504). Madrid: Universidad Complutense, 1980. 
